Boston University School of Law Scholarly Commons at Boston University School of Law

Faculty Scholarship

$2-2013$

\title{
'Petitions Without Number': Widows' Petitions and the Early Nineteenth-Century Origins of Public Marriage-Based Entitlements
}

Kristin Collins

Boston University School of Law

Follow this and additional works at: https://scholarship.law.bu.edu/faculty_scholarship

Part of the Law and Gender Commons

\section{Recommended Citation}

Kristin Collins, 'Petitions Without Number': Widows' Petitions and the Early Nineteenth-Century Origins of Public Marriage-Based Entitlements, 31 Law and History Review 1 (2013).

Available at: https://scholarship.law.bu.edu/faculty_scholarship/74 


\title{
BU School of Law
}

\section{"Petitions Without NumbeR": Widows' Petitions AND THE EARLY NineTEENTH- Century Origins of Public MARRIAGE-BASEd ENTITLEMENTS}

Law \& History Review, Vol. 31, No. 1, February 2013, pp. 1-60

Boston University School of Law Public Law \& Legal Theory No. 11-27

(June 8, 2011)

\author{
Kristin A. Collins \\ Boston University School of Law
}

This paper can be downloaded without charge at:

http://www.bu.edu/law/faculty/scholarship/workingpapers/2011.html 


\title{
"Petitions Without Number": Widows' Petitions and the Early Nineteenth-Century Origins of Public Marriage-Based Entitlements
}

\author{
KRISTIN A. COLLINS
}

\section{Introduction}

In 1858, Catharine Barr wrote to the Pension Commissioner in Washington, D.C., seeking reinstatement of her widow's pension. Barr explained that she had been married to two men who had died in the service of the United States: first to George Bundick, "a young and beloved husband" who had died in the War of 1812; then to William Davidson in 1835, who had died in 1836 of injuries sustained while serving on the USS Vandalia. ${ }^{1}$

1. File of Catharine Davidson, National Archives and Records Administration, Washington, D.C. (hereinafter NARA), Records of the Department of Veterans Affairs, RG 15, Old Wars Pension Files, Widow's File 322, Catharine Barr to George

Kristin A. Collins is a professor of law at Boston University School of Law $<$ collinsk@bu. edu $>$. This article has benefited enormously from suggestions generously offered by numerous colleagues, including Nancy Cott, Nan Goodman, Sally Gordon, Linda Kerber, Andrew Kull, Gerry Leonard, Melissa Murray, Jim Pfander, Robert Self, Kate Silbaugh, David Tanenhaus, and the anonymous reviewers of Law and History Review. An earlier version of this article was selected for presentation at the 2010 Law \& Humanities Junior Scholars Workshop at Columbia Law School, where the author was given extraordinarily thoughtful feedback. She also received helpful comments from participants at the Boston College Legal History Round Table; the Boston University School of Law Faculty Workshop; the annual meeting of the Association for the Study of Law, Culture, and the Humanities; and the Emerging Family Law Scholars Conference. She is indebted to the archivists at the National Archives in Washington, D.C., and the Georgetown University Library Special Collections Research Center for their expert help navigating those collections, and to Emily Cardy, Stephanie Hoffman, Eric Hsu, Jarrod Schaeffer, and Regina Won for excellent research assistance. Finally, she owes special thanks to Norman Lewis, a great-great-great-great grandnephew of Catharine Barr, who helped reconstruct Barr's marital history by sharing family records. The research for this article would not have been possible without the support of the Peter Paul Career Development Fund of Boston University. 
She acknowledged that she was not, strictly speaking, a widow, as her current husband, James Barr, was still living and they were still married. ${ }^{2}$ She nevertheless sought reinstatement of the pension she had been granted as Davidson's widow. Pursuant to the terms of the relevant pension statute, Barr's pension had terminated upon her remarriage to James. However, as Barr explained to the commissioner, James "has neither been with me or given me one Dollar for my support since 1849, and I know not his whereabouts." 3 Having also lost her father in the War of 1812, Barr saw herself as particularly deserving of the federal government's assistance and believed that she and other widows in her position had a claim on the national coffers. "I for one," she implored, "have no Dependence on Earth only what comes through my relations."4

Catharine Barr was one of tens of thousands of women who, from the 1790s through the onset of the Civil War, sought and received assistance from the federal government as military widows. ${ }^{5}$ During a period known for its paltry and punitive local poor laws, Congress enacted approximately seventy-six public law statutes granting cash pensions to large classes of widows of soldiers and veterans who had served in the United States military. ${ }^{6}$ Although war widows' pensions were not unknown in Anglo-American law, this system of social provision for

C. Whiting, Commissioner of Pensions, June 20, 1858. See also, ibid., Catharine Davidson to Secretary of the Navy, February 14, 1842. Catharine Barr's maiden name was Dorgan but her widow's pension application is filed under her second husband's name, William Davidson, and hence I cite to her pension file using that last name. When referring to Catharine in the text, however, I refer to her as Barr, as that was her name during her final and, to my knowledge, longest pursuit of a widow's pension. When citing to particular letters in footnotes, I use the name she used to sign the letter, that is, Catharine Davidson or Catharine Barr.

2. See ibid., Catharine Davidson to Commissioner of Pensions, September 8, 1858. Although Barr does not reveal as much in her letters to the Pension Office, by 1858 she had been married at least five times. In addition to her marriages to Bundick, Davidson, and Barr, records suggest that she married Samie Sniffin in 1818 or thereabouts and Captain Charles Hobday in 1823. See Application of Harriet M. Buhler for Membership in the Daughters of the American Revolution, October 15, 1937 (noting Catherine [sic] Dorgan's marriage to Samie Sniffen in 1818); "Married," N.Y. Spectator, April 29, 1823, at 1 (reporting the marriage of Captain Charles Hobday to Mrs. Catherine [sic] Sniffen).

3. File of Catharine Davidson, NARA, Records of the Department of Veterans Affairs, RG 15, Old Wars Pension Files, Widow's File 322, Catharine Barr to George C. Whiting, Commissioner of Pensions, September 8, 1858.

4. Ibid., Catharine Barr to George C. Whiting, Commissioner of Pensions, June 20, 1858.

5. See below note 29 .

6. See, for example, statutes cited below in notes 17, 19, 20, 22, and 26. See also Kristin A. Collins, "Administering Marriage: Marriage-Based Entitlements, Bureaucracy, and the Legal Construction of the Family," Vanderbilt Law Review 62 (2009): 1085-167. 
military widows departed from English and colonial precedent in significant ways. First, starting in the 1810 s, Congress gradually began providing pensions to widows of rank-and-file soldiers, thus deviating from the classsalient approach of eighteenth-century widows' pensions - both English and American - which had privileged the widows of officers. Second, and as significant, in the 1830 s, Congress began providing service-based pensions to large classes of widows of veterans, also regardless of rank, thereby providing a kind of old-age pension for thousands of women whose husbands had not died in battle. By the 1830s, military widows' pensions were no longer an entitlement tied to privilege and status, or an ad hoc form of relief for particularly sympathetic individual widows. Rather, they were a form of financial assistance, created by public law statutes, intended to alleviate pinching poverty for a significant class of women. Catharine Barr's plea for a pension thus serves as a lens through which to view an important but often overlooked early nineteenth-century phenomenon: the development of the first centralized broad-scale system of public marriage-based entitlements in American law.

Publicly funded marriage-based entitlements are commonplace today, but they were a novelty in the early nineteenth century. In that era, one of the primary purposes of marriage was to contain liability for women's financial needs within the private family, so as not to open up government coffers to claims by wives, widows, and other family dependents. ${ }^{7}$ Given recent debates concerning the scope and propriety of marriage-based entitlements in American law and policy, scholars have asked surprisingly few questions about the earliest origins of this form of centralized social provision. ${ }^{8}$ Through an investigation of the development of military widows'

7. See Ariela R. Dubler, "In the Shadow of Marriage: Single Women and the Legal Construction of the Family and the State," Yale Law Journal 112 (2003): 1658-59.

8. Theda Skocpol's pathbreaking study of Civil War military pensions illuminated the significance of military pensions as a form of social provision, and in particular provision made for widows and other family dependents. See Protecting Soldiers and Mothers: The Political Origins of Social Policy in the United States (Cambridge, MA: Harvard University Press, 1992). However, Skocpol references pre-Civil War veterans' and widows' pensions in passing only, noting that "the expansions of U.S. military pensions prior to the 1860 s were minimal compared to what was to come with the mass-mobilizing Civil War and its political aftermath." Ibid., 105. Alice Kessler-Harris's study of the Social Security Act of 1939 and related early twentieth-century legislation probes the modern history of social provision for women predicated on marriage. See In Pursuit of Equity: Women, Men and the Quest for Economic Citizenship in 20th-Century America (New York: Oxford University Press, 2001). Linda Gordon has focused on the development of mothers' aid statutes and "welfare" for mothers from the Progressive period through the New Deal. See Linda Gordon, Pitied but Not Entitled: Single Mothers and the History of Welfare, 1890-1935 (Cambridge, MA: Harvard University Press, 1994). However, attention to social provision for women in the early nineteenth century has largely focused on local poor law legislation and charity, 
pensions in the early nineteenth century, this article takes a fresh look at the history of social provision for women, marriage-based entitlements, and women's experience of the law during this period. Elsewhere, I have focused on the sizable and complex administrative system that developed to administer military pensions in the early nineteenth century, and widows' navigation of that bureaucracy. ${ }^{9}$ Here, my concern is the widows' interaction with Congress and the fundamental but complex question of causation: Why, in the early nineteenth century, did Congress come to subsidize marriage on a significant scale?

Although the forces leading to the development of a significant and complex system of military widows' pensions in the early nineteenth century were many, this article focuses on the important role played by widows' pension petitions to Congress, both because they were instrumental in the development of this particular form of entitlement and because they are an under-examined instance of women's participation in early nineteenth-century American legal and political life. In so doing, this article helps illuminate how marriage-based entitlements became entrenched in American law and social policy, forming part of our common sociolegal understanding of what it means to be married.

Women's petitioning practices of the early nineteenth century have not escaped the notice of historians. Much of that attention has focused on women's overtly reform-oriented petitioning efforts, such as the abolitionist petitions that flooded Congress in the 1830s and 1840s, and the petitions opposing Indian removal of the same period. ${ }^{10}$ Over the course of the early nineteenth century, however, hundreds of women engaged in an arguably more pedestrian mode of petitioning by making formal requests to Congress for pensions based on their status as military widows. Their stories, and the role of their petitions in transforming military widows' pensions from a rarefied, class-salient privilege to a broad-scale entitlement, are the focus of this article.

rather than centralized, government-funded systems of entitlement. See, for example, Mimi Abramovitz, Regulating the Lives of Women: Social Welfare Policy from Colonial Times to the Present (Boston: South End Press, 1989), 181-213.

9. See Collins, "Administering Marriage," 1122-56.

10. See, for example, Lori D. Ginzberg, Untidy Origins: A Story of Women's Rights in Antebellum New York (Chapel Hill: University of North Carolina Press, 2005); Alisse Portnoy, Their Right to Speak: Women's Activism in the Indian and Slave Debates (Cambridge, MA: Harvard University Press, 2005); Susan Zaeske, Signatures of Citizenship: Petitioning, Antislavery, and Women's Political Identity (Chapel Hill: University of North Carolina Press, 2003); and Mary Hershberger, "Mobilizing Women, Anticipating Abolition: The Struggle Against Indian Removal in the 1830s," Journal of American History 86 (1999): 15-40. 
To explain the petitioning process and the role of widows in shaping these early marriage-based entitlements, this article first details the experiences of two early nineteenth-century widows, Susan Decatur and Catharine Barr. Decatur and Barr took very different routes to obtaining their pensions. Decatur, the widow of the famous commodore Stephen Decatur, petitioned Congress directly in pursuit of a private act: a law enacted for the benefit of a named individual. Barr sought pensions pursuant to several of the public or general law widows' pension statutes that Congress enacted in the early nineteenth century. Standing alone, the stories of Decatur and Barr provide a window into individual women's negotiation of state power in the early nineteenth century-experiences undoubtedly marked by class and circumstance. But precisely because of the differences in Barr's and Decatur's experiences, their stories also provide important clues concerning the evolution of military widows' pensions. By situating these two women's experiences within the more general legislative history of the widows' pension system, we see that an important force leading to the development of the first centralized system of marriage-based entitlements was the formal assertion by widows to Congress that, in certain circumstances, marital status should serve as a basis for government support.

In making the case for widows' pensions, widows and their supporters drew on contemporary notions of domesticity and allied conceptions of men's status as citizen-soldiers. In this respect, widows' petitions provide a rich example of how women of the early nineteenth century deployed powerful gender conventions in an effort to achieve particular goals, a strategy that historians have traced in other late eighteenth- and early nineteenth-century contexts. ${ }^{11}$ In the case of widows' pension petitions, that discursive strategy helped translate a set of powerful beliefs about women's and men's proper roles and capacities into a legal claim for federal material support - and not just for the Susan Decaturs of the world, but for common women like Catharine Barr as well.

11. There is a robust and expanding literature exploring the various ways that women harnessed contemporary gender conventions in their efforts to shape government practices and civil society in the early nineteenth century. See, for example, Rosemarie Zagarri, Revolutionary Backlash: Women and Politics in the Early American Republic (Philadelphia: University of Pennsylvania Press, 2007); Elizabeth R. Varon, We Mean to Be Counted: White Women and Politics in Antebellum Virginia (Chapel Hill: University of North Carolina Press, 1998); Mary P. Ryan, Women in Public: Between Banners and Ballots, 1825-1880 (Baltimore: Johns Hopkins University Press, 1990), 130-41; Linda K. Kerber, Women of the Republic: Intellect and Ideology in Revolutionary America (Chapel Hill: University of North Carolina Press, 1980), 85; and Lori D. Ginzberg, "Moral Suasion Is Moral Balderdash': Women, Politics, and Social Activism in the 1850s," Journal of American History 73 (1986): 601-22. 
Two preliminary remarks are in order. First, this is not a story about boundless congressional generosity to "worthy widows," or about the radical democratization of women's rights as wives. Many widows' petitions for individual relief were, in fact, denied. However, considered collectively, such petitions prompted substantial legislative debate concerning the scope and basis of the government's obligation to support widows, and helped give rise to programmatic support for widows through general legislation.

Second, it is worth emphasizing that neither widows' pension petitions, nor the gender-based ideology on which they frequently drew, did all of the work. A whole host of factors influenced the development of military widows' pensions in crucial ways, including economic and political trends, broader changes in legislative practice, and an early nineteenth-century culture of militarism. My goal in focusing on the importance of widows' petitions is not to diminish the significance of these other factors, but rather to highlight the particular political and legal process through which women helped to bring about a significant transformation in government policy, even (or especially) as they relied on a constellation of gender-based beliefs that also served to circumscribe women's claims to full citizenship in other contexts. ${ }^{12}$

The petitioning process was itself bound in part by gender-conventional expectations concerning women's engagement with the state. But however humble their discursive conventions, widows' petitions put women's financial needs on the national legislative agenda, brought attention to the inequity of inherited class-salient practices, and informed the way national legislators reasoned about women's claims on, and their position within, the polity. To overlook widows' petitions in an analysis of the development of military widows' pensions would result in an anemic account of the evolution of social provision for women. Drawing on deeply held beliefs concerning women's dependency and proper social role, while simultaneously asserting new claims on the polity, widows' petitions helped

12. By focusing on widows' petitions as an important factor in the emergence of military widows' pensions, this article builds on and attempts to bridge two analytical approaches that have tended to dominate discussions of the development of broad-scale systems of social provision: the institutional-political process approach favored by political scientists (see, for example, Margaret Wier, Anna Shola Orloff, and Theda Skocpol, The Politics of Social Policy in the United States [Princeton: Princeton University Press, 1988], 40-41), and feminist historians' keen attention to the role of gender ideology in the evolution of redistributive systems (see Kessler-Harris, In Pursuit of Equity; Abramovitz, Regulating the Lives of Women; and Barbara Nelson, "The Origins of the Two-Channel Welfare State: Workmen's Compensation and Mothers' Aid," in Women, the State, and Welfare, ed. Linda Gordon [Madison: University of Wisconsin Press, 1990], 123-51). 
initiate a lasting change in American law and policy: the development of the public marriage-based entitlement.

\section{The First System of Public Marriage-Based Entitlements}

Today, the death of one's spouse can trigger all manner of public and private compensation for the surviving widow or widower, including Social Security survivors' benefits, workers' compensation, life insurance benefits, and tort remedies in wrongful-death actions. However, the law has not always been so focused on the financial security of surviving spouses. Early nineteenth-century law provided for widows and widowers through intestacy law and related doctrines such as dower and curtesy, but the scope of such provision was limited. ${ }^{13}$ Certainly, the notion that a spouse's death could trigger the allocation of public assets was not understood as a natural consequence of the marital relationship. Under eighteenth-century Anglo-American law and policy, the vast majority of war widowswomen who would seem to have had the greatest claim on the polity's sympathy and resources - went uncompensated for their husbands' deaths. The system of federal military widows' pensions that developed in America over the course of the early nineteenth century marked an important departure: the creation of legal entitlements to public monies for a significant class of women, based on their marriage to a worthy husband. ${ }^{14}$

Anglo-American governments had provided for some military widows, but such provision was of a different scope and kind. In eighteenth-century England, pensioning the widows of officers was a fairly common practice, but systematic provision for widows of soldiers was not available until the end of the nineteenth century. ${ }^{15}$ American colonial governments adopted a similar class-salient approach to war widows' pensions, generally providing significant pensions to the widows of officers as a matter of course, but providing for the widows of soldiers, if at all, though poor-law types of statutes that were based on need and limited to subsistence-level support. ${ }^{16}$ This pattern persisted on the federal level from the Revolutionary

13. See discussion accompanying notes 159-62.

14. This section draws significantly on my description of the early nineteenth-century military widows' pension statutes provided in Collins, "Administering Marriage," 1095-116.

15. See Myna Trustram, Women of the Regiment: Marriage and the Victorian Army (New York: Cambridge University Press, 1984), 92 ("Pensions for officers' widows and orphans originated in the early eighteenth century. NCOs and privates had to wait for almost two centuries before the needs of their families were recognised.").

16. For examples of colonial poor law provision for families of soldiers, see "An Act for Relieving Such as Shall Be Maimed in the Colonies Service, and the Widow, Parents or 
era to the first decade of the nineteenth century: in 1780, the Continental Congress granted pensions to the widows of Revolutionary War officers, an act that Congress later ratified, and a general practice that Congress continued through the early 1810 s. ${ }^{17}$

Congress's first innovation with respect to widows' pensions expanded the socioeconomic reach of the pension system as it applied to what one might call traditional war widows - women whose husbands died in the line of duty - by making such pensions available regardless of the husband's rank. ${ }^{18}$ This equalization of war widows' pensions was an evolutionary rather than a revolutionary process. Two years into the War of 1812, Congress began to provide for traditional war widows of the

Relations of Such as Shall Be Kill'd in the Colonies Service, and Shall Not Be Able to Subsist or Maintain Themselves" (1718) reprinted in The Earliest Acts and Laws of the Colony of Rhode Island and Providence Plantations 1647-1719, ed. John D. Cushing (Wilmington, DE: Michael Glazier, 1977), 228-29; and "An Act to Amend the Act Concerning Pensioners" (1785) in The Statutes at Large; Being a Collection of All the Laws of Virginia, ed. William Waller Hening (Richmond: George Cochran, 1823), 12:105.

17. For examples of acts granting pensions to officers' widows only, see Journals of the Continental Congress, 1774-1789, ed. Worthington C. Ford et al. (Washington, D.C.: Government Printing Office, 1904-37), 17:772-73 (resolution of August 24, 1780 providing pensions to widows of Revolutionary War officers); Act of June 7, 1794, ch. 52, § 1, 1 Stat. 390, 390 (providing 5-year half-pay pensions to widows of commissioned officers who "die by reason of wounds received in actual service of the United States"); Act of March 16, 1802 , ch. 9, $\S 15,2$ Stat. 132, 135 (providing 5-year half-pay pensions to widows of "commissioned officer[s] in the military peace establishment" who "die by reason of any wound received in actual service of the United States"); and Act of January 11, 1812, ch. 14, § 15, 2 Stat. 671, 673 (providing 5-year half-pay pensions to widows of "any commissioned officer in the military establishment of the United States" who died "by reason of any wound received in actual service of the United States").

18. Unlike most widows' service-based pensions, described in the text accompanying notes 24-26, traditional war widows' pension statutes also provided for the children of deceased soldiers and officers, but only in the absence of a widow or upon her death or remarriage. Children were pension eligible until they reached the age of 16 or 21 , or the term-limited pension expired, whichever occurred first. See, for example, Act of April 10, 1812, ch. 54, § 2, 2 Stat. 704, 704; Act of March 19, 1836, ch. 44, § 5, 5 Stat. 7, 7; and Act of March 3, 1837, ch. 38, § 1, 5 Stat. 180, 180. Careful analysis of statutory provision for the children of fallen soldiers is outside the scope of this article. However, a few observations are particularly relevant to understanding the widows' pension statutes. First, it is significant that children were not primary beneficiaries of the pension statutes, given that under contemporary intestacy law children had a direct claim on their fathers' estate that was in certain respects superior to that of the widow. See Collins, "Administering Marriage," 1111-12. Second, although traditional war widows' pensions extended to orphans in some circumstances and were often justified based on widows' actual or presumed service as mothers, motherhood was not required for widows' pension eligibilityonly marriage. Accordingly, a widows' pension eligibility turned on the existence of a legal marriage, a point I explore in detail in "Administering Marriage," 1130-40. 
rank-and-file; first to widows of privateers and navy seamen, and next to widows of army soldiers. ${ }^{19}$ In subsequent years, Congress regularly enacted general pension statutes for the benefit of widows of seamen who perished in ongoing naval encounters and widows of soldiers who died in "frontier wars." 20 Until the 1830 s, however, the default rule in statutes governing the military establishment was to provide pensions to the war widows of officers only. ${ }^{21}$

In 1836, Congress enacted two watershed statutes that dramatically expanded the socioeconomic reach of widows' pensions. First, in March of that year, it provided a 5-year pension to the widow of any "officer, noncommissioned officer, musician, artificer, or private, of volunteer and militia corps, who shall die in the service of the United States,"22 thus creating a blanket provision for the war widows of men of all ranks. In so doing, Congress departed from the class-salient default rule that had tended to characterize traditional war widows' pensions in Anglo-American law for at least 200 years. $^{23}$

Then, in July of the same year, Congress took the equally significant step of introducing broad-scale service-based pensions to large classes of Revolutionary War widows, including widows of soldiers. Widows'

19. Act of March 4, 1814, ch. 20, §§ 1-2, 3 Stat. 103, 103; and Act of April 16, 1816, ch. $55, \S \S 1-2,3$ Stat. $285,285-86$.

20. See, for example, Act of March 3, 1817, ch. 60, § 1, 3 Stat. 373, 373-74 (providing 5 -year half-pay pensions to widows of navy officers, seamen, and marines who had died, or were to die, in the line of duty after June 18, 1812); Act of April 20, 1818, ch. 101, §2, 3 Stat. 459, 459 (granting 5-year half-pay pensions to widows of militia who "prosecut[ed] the war against the Seminole tribe of Indians"); and Act of May 23, 1828, ch. 72, § 1, 4 Stat. 288, 288 (granting 5-year extension of pensions awarded to widows of all "officers, seamen and marines" killed in the War of 1812).

21. See sources cited in note 17.

22. Act of March 19, 1836, ch. 44, § 5, 5 Stat. 7 (emphasis added).

23. In English law, there was a brief but important exception to the class-salient approach to military widows' pensions in the mid-seventeenth century. Following the English Civil War, soldiers' war widows were eligible to receive pensions from a fund established by the short-lived republican Commonwealth government, as long as the widow could demonstrate poverty as a result of her husband's death. See Geoffrey L. Hudson, "Negotiating for Blood Money: War Widows and the Courts in Seventeenth-Century England," in Women, Crime and the Courts in Early Modern England, ed. Jennifer Kermode and Garthine Walker (Chapel Hill: University of North Carolina Press, 1994), 151-52. Hudson explains, however, that after the demise of that system with the restoration of the monarchy, widows of English soldiers would not receive pensions "for over 200 years." Ibid., 146. Isser Woloch has excavated another republican experiment with pensions for the widows of soldiers in France at the end of the eighteenth century. However, France's experiment with the pension alimentaire for soldiers' widows was also short lived, ending in the 1810s. See Isser Woloch, "War-Widows Pensions: Social Policy in Revolutionary and Napoleonic France," Societas 6 (1976): 238-40. 
service-based pension statutes benefited women whose husbands died long after their military service had concluded, almost always of causes unrelated to that service. The Act of July 4, 1836 awarded lifetime pensions to the widows of "officers, marines, mariners, musicians, and soldiers" who had served in the Revolutionary War for at least 6 months, "whose marriage took place before the expiration of [their] last period of service," and who had never remarried. ${ }^{24}$ The women pensioned under this Act were not the young widows of fallen soldiers who usually come to mind when we think of war widows. As one committee report explained, "[t]he provisions of the act [of 1836] were clearly intended to sustain the widow in her declining life." ${ }^{25}$ Through several general pension statutes enacted between 1837 and 1853, Congress expanded the categories of widows eligible for service-based pensions, thus promising cash assistance to the many thousands of women who had been married to a Revolutionary War veteran at some point in their lives. ${ }^{26}$

These two significant shifts - the leveling of traditional war widows' pensions and the creation of service-based widows' pensions for Revolutionary War widows - spawned a significant system of centralized public marriage-based entitlements. This system was not completely free of the rank-based obsession of the military, as the amount awarded to

24. See Act of July 4, 1836, ch. 362, § 3, 5 Stat. 127, 128. Section 3 of the July 4, 1836 statute extended the Revolutionary War veterans' service-based pensions, created in 1832, to veterans' widows. See Act of June 7, 1832, ch. 126, § 1, 4 Stat. 529, 529-30. Pursuant to Section 3, the widow received the same amount that her husband had received under the 1832 Act. Thus, widows whose husbands had served in the Revolutionary War for at least 2 years received full pay for life (capped at the pay of a captain) and widows whose husbands had served between 6 months and 2 years received pensions prorated based on their length of service. See Act of July 4, 1836, § 3; and Act of June 7, 1832, § 1 .

25. Committee on Revolutionary Pensions, Huldah Pennyman, H.R. Rep. No. 24-235, 1 (1837).

26. See, for example, Act of March 3, 1837, ch. 42, § 2, 5 Stat. 187, 187 (granting lifetime pensions to widows who had married a Revolutionary War veteran prior to 1783); Act of July 7, 1838, ch. 189, $\S 1,5$ Stat. 303, 303 (granting 5-year pensions to widows who had married a Revolutionary War veteran prior to 1794); Act of March 3, 1843, ch. 102, § 1, 5 Stat. 647, 647 (granting a 1-year extension of pensions awarded to widows pursuant to the Act of July 7, 1838); Act of June 17, 1844, ch. 102, §§ 1-2, 5 Stat. 680, 680 (granting a 4-year extension of pensions awarded to widows pursuant to the Act of July 7, 1838); Act of February 2, 1848, ch. 8, §§ 1-2, 9 Stat. 210, 210-11 (transforming widows' pensions awarded under the Act of July 7, 1838 into lifetime pensions); Act of July 29, 1848, ch. $120, \S 1$, 9 Stat. 265, 265-66 (granting lifetime pensions to Revolutionary War widows married prior to 1800); and Act of February 3, 1853, ch. 41, § 2, 10 Stat. 154, 154 (granting lifetime pensions to Revolutionary War widows, regardless of when their marriage to a veteran took place). 
individual widows was calibrated largely to the husband's rank. ${ }^{27}$ And it would be a serious overstatement to characterize this complicated constellation of widows' pension statutes as a system of universal entitlements. They were part of the advent of an enduring form of provision in American social policy: the selective entitlement. ${ }^{28}$ Nevertheless, these statutes created a far-reaching program of social provision that benefited tens of thousands of women. Based on early nineteenth-century records collected by the Pension Office and submitted to Congress, between 1836 and the outbreak of the Civil War, more than 47,000 widows collected pensions under federal pension laws. ${ }^{29}$

27. The amount an individual widow received as a pension corresponded to her husband's rank because her pension was calculated according to the soldier's or officer's pay, although pensions were generally capped at a particular rank, such as captain or lieutenant colonel. See, for example, Act of June 7, 1794, ch. 52, § 1, 1 Stat. 390, 390; Act of April 10, 1812, ch. 54, § 2, 2 Stat. 704, 705; Act of July 4, 1836, ch. 362, § 3, 5 Stat. 127, 128; and Act of February 3, 1853, ch. 41, § 1, 10 Stat. 154, 154.

28. Laura Jensen makes this important point with respect to veterans' service-based pensions, which Congress expanded significantly in the 1810s and 1820s. See Laura Jensen, Patriots, Settlers, and the Origins of American Social Policy (New York: Cambridge University Press, 2003), 9-12.

29. My estimate that at least 47,000 widows collected pensions from 1836 to 1860 exceeds estimates offered by William Glasson and John Resch, both of whom placed the number at approximately 23,000. See William H. Glasson, Federal Military Pensions in the United States (New York: Oxford University Press, 1918), 95-96; and John Resch, Suffering Soldiers: Revolutionary War Veterans, Moral Sentiment, and Political Culture in the Early Republic (Amherst: University of Massachusetts Press, 1999), 203. In large part, this is because Glasson and Resch included only Revolutionary War widows in their estimates, whereas my calculation includes traditional war widows who received pensions between 1836 and 1861. Accordingly, there is no actual inconsistency between my estimates and theirs, although the lower estimates are misleading if they are understood to represent the full scope of early nineteenth-century military widows' pensions. My calculation is based on careful examination of data contained in early nineteenth-century reports by the Commissioner of Pensions to Congress. The vagaries of early nineteenth-century record keeping make any estimation imperfect, and when in doubt I erred on the side of undercounting the number of widows receiving pensions. See Loren Pinckney Waldo, Report of the Commissioner of Pensions, H.R. Exec. Doc. No. 33-1, 1:488, 495 (1st Sess. 1853); Loren Pinckney Waldo, Report of the Commissioner of Pensions, S. Exec. Doc. No. 33-1, 1:55859 (2nd Sess. 1854); J. Minot, Report of the Commissioner of Pensions, H.R. Exec. Doc. No. 34-1, 1:594 (1st Sess. 1855); J. Minot, Report of the Commissioner of Pensions, H.R. Exec. Doc. No. 34-1, 1:848 (3rd Sess. 1856); George C. Whiting, Report of the Commissioner of Pensions, H.R. Exec. Doc. No. 35-2, 2:706-9 (1st Sess. 1857); George C. Whiting, Report of the Commissioner of Pensions, H.R. Exec. Doc. No. 35-2, 2:676-79 (2nd Sess. 1858); George C. Whiting, Report of the Commissioner of Pensions, S. Exec. Doc. No. 36-2, 1:825-28 (1st Sess. 1859); and George C. Whiting, Report of the Commissioner of Pensions, S. Exec. Doc. No. 36-1, 1:470-73 (2nd Sess. 1860). 
Of course, numbers do not tell the entire story. Widows' military pension statutes not only created new entitlements for a significant group of women, but also reflected and disseminated important social knowledge about women's legal rights as wives. As I have examined elsewhere, federal military widows' pensions of this period were supported and implemented by a significant administrative apparatus that reached from the Pension Office of the War Department in Washington, D.C., to individual local banks that issued payments on widows' pension certificates. ${ }^{30}$ The enactment of public law pension statutes thus ushered large numbers of widows into the federal administrative system that evolved to determine individuals' pension eligibility, an experience that undoubtedly shaped those women's understanding of their status in the polity as wives and widows. Widows' pension applications reveal the unsurprising but important fact that military widows were aware of the pensions awarded to other widows, and that they talked to each other-in town, in church, at the market - about the pension laws and the availability of pensions for different categories of widows. ${ }^{31}$ These new statutory rights for widows were routinely and prominently reported in newspapers around the country, creating a direct connection between the federal government and individual women, between Washington and scattered localities, between nation and neighborhood. ${ }^{32}$ Pension claims agents - a class of middlemen who, for a fee, assisted both widows and veterans with their military pension applications - disseminated information about widows' new statutory rights while peddling their services. ${ }^{33}$ Widows of soldiers and veterans thus

30. For a detailed discussion of the administration of the widows' pensions, see Collins, “Administering Marriage," 1123-40.

31. See, for example, Committee on Revolutionary Claims, Heir of Richard Wilde, H.R. Rep. 27-357 (1842) (petition reports that the "widow of Lieutenant Wilde had often applied to her friends to get her an allowance for her husband's services, and was always told by them that they knew of no law that would entitle her to receive anything"); Committee on Military Affairs, Pamela Adams, H.R. Rep. 23-328, 2 (1834) (widow's petition notes that she is seeking a pension "by the advice of friends"). See also text accompanying notes 97 and $128-40$.

32. See, for example, "War Department, Pension Office," Berkshire Journal, May 5, 1831, at 1 (reporting widows' right to arrears under the Act of March 2, 1829, setting forth application procedures, and noting that "printers in the city and country are requested to insert the above for the benefit of revolutionary pensioners"); "Pensions to Widows," Salem Gazette, March 21,1837 , at 2 (reporting that Congress had granted pensions to widows of those who had died in the navy, "whatever was the cause of death, whether they were seamen or marines"); "Information to the Widows and Children of the Revolution, and of Such as Died in the War of 1812," Farmers' Cabinet, December 6, 1839, at 3 (providing basic information regarding widows' pension eligibility under extant acts of Congress).

33. For example, in a declaration submitted to the Pension Office in 1847, Pamela Blackwell of New Jersey explained that "she knew well that she was entitled to a pension 
became a community of women — both real and "imagined" - who, by virtue of their former marriage to a soldier or veteran, had been deemed worthy recipients of government assistance. ${ }^{34}$ The widows' pensions identified marriage as a common condition of women's status in, and claims on, the national polity.

The blossoming of the widows' pension system also marked a significant shift in marriage's sociolegal significance, from recognition of widows' claims on society's benevolence to recognition of widows' legal claims on the polity. Congress's rejection of the petition of one Ruth Roberts in 1790 betrays a prevalent late eighteenth-century attitude toward widows' pensions. During the Revolutionary War, Roberts's husband had suffered serious injuries that prevented him from working his farm and ultimately led to his death. In a report recommending that Congress reject Roberts's pension petition, Secretary of War Knox advised that "although the situation of the petitioner may entitle her to the assistance of all humane persons, yet the circumstances of the case do not appear to be such as to constrain the United States to depart from the principles, practice [s], and limitations established by the late Congress." ${ }^{35}$ Those principles, practices, and limitations did not provide for widows like Ruth Roberts, at least not in 1790 .

By 1854, however, pension treatise writers Robert Mayo and Ferdinand Moulton could announce that "widows and orphans, being the natural and civil dependents of their husbands and fathers whilst living, might therefore be considered as justly entitled to the continuance, nay the inheritance, of the right, virtually as a vested right, of [a] pension, at the death of their said natural and civil protectors." ${ }^{36}$ It had taken national legislators several decades to reach the conclusion that marriage could give large

from the Government soon after the passage of that law"- the Act of July 4, 1836 - as "she was visited by a number of agents to draw papers and prosecute her claim." File of Pamela Blackwell, NARA, RG 15, microfilmed on Records of the Veterans' Administration, Revolutionary War Pension and Bounty Land Application Files, 1800-1900 (1974), Series M804 (hereinafter "Series M804"), W 839, Declaration of Pamela Blackwell, April 5, 1847. For a detailed discussion of the pension claims agents and their function in the pension claims process, see Collins, "Administering Marriage," 1124-27.

34. The phrase "imagined community" is, of course, Benedict Anderson's, and it refers to the power of various mechanisms - including newspapers - to build a sense of nationalism in the absence of direct contact between members of a national polity. Benedict Anderson, Imagined Communities: Reflections on the Origin and Spread of Nationalism (New York: Verso, 1983).

35. Report of Secretary of War Knox to Congress on the Claim of Ruth Roberts, February 5, 1790, American State Papers: Claims, 1:5-6.

36. See Robert Mayo and Ferdinand Moulton, Army and Navy Pension Laws, and Bounty Land Laws of the United States, 2nd ed. (Baltimore: Lucas Brothers, 1854), XXVI-XXVII. 
classes of women claims on the public treasure, and to enact and implement a body of laws and administrative processes that facilitated this understanding.

\section{The Expansion and Leveling of Widows' Pensions}

Why did Congress get into the business of providing military widows' pensions to such a broad cross-section of women? In particular, why the shift from a limited and relatively inexpensive pension system that privileged the widows of officers to one in which tens of thousands of women became entitled to military pensions on the basis of their marriage to a man who had died during his service, or simply served, in the military? Of course, there is no single explanation for such a complex phenomenon. But any answer must be sensitive to political and legal strategies open to women, and to women's very limited formal agency at the time, while also accounting for contemporary changes, pronounced and subtle, in the ideological valences of family and gender. Widows' pension petitions have received little sustained attention, but they are an obvious and important source of evidence of how the financial needs of large classes of widows became a politically legitimate, and at times pressing, subject of federal legislation.

The widows' pension petitions are in many respects a study in the reproduction of gender-conventional norms in public law. As discussed in greater detail below, widows' petitions relied upon, and reinforced, the centrality of men's and women's traditional gendered roles: men's service as citizen-soldiers and women's service as wives and mothers; men's status as heads of household and women's dependency within the household. It would be a mistake, however, to understand widows' pension petitions, or the pensions themselves, as wholly conventional in their ambitions and influence. Wives had long been considered their husbands' dependents under the law, and husbands their wives' protectors and providers. However, before the early nineteenth century, such private dependency had not translated into public support for the vast majority of military widows, even when their husbands died in service to country. The expansion of widows' pensions thus signaled a growing consciousness of wives' domestic responsibilities and dependent status as matters of public, and even national, significance that could, under certain circumstances, justify public material support for widows across the socioeconomic spectrum. ${ }^{37}$

37. For two foundational examinations of the development of the concept of domesticity in the early nineteenth century, see Nancy F. Cott, The Bonds of Womanhood: "Women's Sphere" in New England, 1780-1835 (New Haven: Yale University Press, 1977); and 
To help understand this shift in the provision of military widows' pensions, and the role of widows' petitions in bringing about this shift, it is useful to compare the experiences of two widows, Susan Decatur and Catharine Barr. Decatur's saga is a story of Old World mores and the patronage politics of Washington, D.C. The experience of Decatur, a woman of extraordinary wealth and political connections, simultaneously sheds light on the significant role of petitioning and reveals Congress's increased skepticism of the hierarchical, class-salient widows' pensions that typified both English and colonial pension laws of the eighteenth century. Catharine Barr, on the other hand, was a woman of little means or apparent influence. Her navigation of the pension system and success (albeit mixed) in obtaining a pension demonstrate the equalization and expansion of the widows' pension system, and the concomitant entrenchment of marriage as a privileged, public institution deep into the ranks of society. ${ }^{38}$

Neither Decatur nor Barr represents the thousands of widows who sought military pensions during the early nineteenth century. Nevertheless, their stories illustrate how women's assertions of formal claims on the federal government helped give rise to a broad-scale system of social provision for widows, shaping - sometimes in unintended wayswomen's rights, women's legal consciousness, and, ultimately, women's relationship to the polity.

\section{A. Susan Decatur}

In 1806, Susan Wheeler married the young naval hero Stephen Decatur. Although she came from a prominent Norfolk family, her marriage to Stephen catapulted her into the most rarefied social and political circles of the period. When the couple met, Stephen was already well known for his first widely celebrated act of heroism: during the Barbary Wars, he had led a successful mission to destroy a captured American vessel, the USS Philadelphia. ${ }^{39}$ This feat earned Stephen, then 25 years of age, worldwide fame, including the attention of Lord Admiral Nelson, who is

Kathryn Kish Sklar, Catharine Beecher: A Study in American Domesticity (New York: Norton, 1973).

38. This point draws on Nancy Cott's important observation that the Civil War widows' pension system, "reaching far into the ranks of the very poor ..., reinforced the standard that the husband and father was the provider and family members his dependents." See Nancy F. Cott, Public Vows: A History of Marriage and the Nation (Cambridge, MA: Harvard University Press, 2000), 103.

39. James Tertius de Kay, A Rage for Glory: The Life of Commodore Stephen Decatur, USN (New York: Free Press, 2004), 45-60. 
said to have commented that it was "the most bold and daring act of the age." 40 In addition to the honors and medals, Stephen accumulated another kind of reward in his 10 years of active naval service: prize money. ${ }^{41}$ In 1818 , just after he was appointed navy commissioner, the socially and politically ambitious couple built a mansion on President's Park, near the White House, thereby taking their place among the Washington elite. ${ }^{42}$

Theirs was a society of Old World tradition, including - especially among its military members - the honor-bound tradition of dueling. ${ }^{43}$ In 1820, James Barron challenged Stephen to a duel in response to allegedly slanderous remarks he had made concerning Barron's activities during the Chesapeake-Leopard Affair. As an officer and a gentleman, Stephen had little choice but to accept Barron's challenge. ${ }^{44}$ Legend has it that Stephen was perhaps too much a gentleman and, at the critical moment, intentionally aimed low, only slightly wounding Barron. Barron shot to kill. Stephen's honor was preserved, but his life was not. It is testimony to his status as a national hero that President Monroe, the Supreme Court Justices, and most of Congress attended his funeral. ${ }^{45}$

At the moment that she had assumed the role of grand hostess in the nation's capital, Susan Decatur was left a widow. The couple was childless, and under Stephen's will she inherited his entire fortune, including $\$ 75,000$, the mansion on President's Park, and sundry other properties. ${ }^{46}$ However, within 5 years profligate spending and mismanagement of her fortune left Decatur in what she considered to be dire straits. ${ }^{47}$ She did not qualify for a pension under a general pension statute because

40. Ibid., 59.

41. For a detailed and illuminating discussion of the prize-money system and its dissolution in the nineteenth century, see Nicholas Parillo, "The De-privatization of American Warfare: How the U.S. Government Used, Regulated, and Ultimately Abandoned Privateering in the Nineteenth Century," Yale Journal of Law and the Humanities 19 (2007): 23-26.

42. de Kay, A Rage for Glory, 174. For a discussion of elite Washington society during this period, and especially the role of women in patronage politics, see Catherine Allgor, Parlor Politics: In Which the Ladies of Washington Help Build a City and a Government (Charlottesville: University of Virginia Press, 2000), 128-46.

43. For a discussion of the code of honor that governed dueling in early nineteenthcentury America, see Alison L. LaCroix, "To Gain the Whole World and Lose His Own Soul: Nineteenth-Century American Dueling as Public Law and Private Code," Hofstra Law Review 33 (2004): 501-69.

44. de Kay, A Rage for Glory, 177-92.

45. Charles Lee Lewis, The Romantic Decatur (Philadelphia: University of Pennsylvania Press, 1937), 232-33.

46. Ibid., 279 nn.103,105.

47. Ibid., 279 n. 105. 
Stephen had not died "by reason of a wound received in the line of his duty," as the contemporary pension laws typically required. ${ }^{48}$ Hence, in 1825 , Decatur did what any sensible widow of a famous navy officer steeped in the capital city's distinctive culture of society and patronage would do: she petitioned Congress for support.

Decatur's initial petition was not styled as a pension bill. Rather, she asserted a claim for substantial prize money "in behalf of herself and of the officers and crew" allegedly owed to Stephen and the other men involved in the destruction of the USS Philadelphia in 1804. ${ }^{49}$ Although her petition did not deign to propose a dollar amount for the prize money owed, her advocates in the House of Representatives did: $\$ 100,000$, a princely sum. ${ }^{50}$ Because Stephen commanded that particular mission, Decatur stood to collect at least $\$ 15,000 .{ }^{51}$ Decatur's claim languished for over a decade, during which time she indeed became near penniless, at least by the standards of the American gentry. Between 1825 and 1836, Decatur renewed or resubmitted her petition to Congress several times, ${ }^{52}$ resulting in a raft of committee reports and numerous prolonged floor debates. ${ }^{53}$ In 1836, she was forced to sell the President's Park

48. See, e.g., Act of March 4, 1814, ch. 20, § 2, 2 Stat. 103 (granting pensions to widows whose husbands "shall die . . by reason of a wound received in the line of his duty"). See also Susan Decatur, H.R. Rep. No. 34-306 (1856) (reprinting J. Minot, Pension Commissioner, to Hon. S.R. Mallory, Chairman, Senate Committee on Naval Affairs, May 14, 1856); see source cited in note 214.

49. Committee on Naval Affairs, On the Claim of Mrs. Susan Decatur, Widow of Commodore Stephen Decatur for Prize Money, for the Capture and Destruction of the Frigate Philadelphia, at Algiers, H.R. Rep. No. 19-281, at 484-86 (1826).

50. Committee on Naval Affairs, Destruction of Frigate Philadelphia, H.R. Rep. No. 1974 , at 10 (1827).

51. See ibid.; Committee on Naval Affairs, On the Claims of the Survivors and Legal Representatives of the Officers and Crew of the Ketch Intrepid, Commanded by Captain Stephen Decatur, and others, for Remuneration for the Destruction of the Frigate Philadelphia at Tripoli, in 1804; and Recommending the Distribution of $\$ 100,000$ Amongst Them in the Proportion Stated, H.R. Rep. No. 24-595 (1836).

52. See Digested Summary and Alphabetical List of Private Claims Presented to the House of Representatives from the 1 st to the 31st Congress (Washington, DC: Wm. M. Belt, 1853).

53. See, for example, Committee on Naval Affairs, Destruction of Frigate Philadelphia, H. R. Rep. No. 19-74 (1827); Committee on Naval Affairs, On Senate Bill No. 50-Susan Decatur, et al., H.R. Rep. No. 20-201 (1828); Case of Susan Decatur, et al., H.R. Rep. No. 21-60 (1830); On Claim of Mrs. Susan Decatur and Others, H.R. Rep. No. 21-398 (1830); Case of Susan Decatur, et al., H.R. Doc. No. $22-27$ (1831); Committee on Naval Affairs, Susan Decatur, H.R. Rep. No. 23-45 (1833); Committee on Naval Affairs, On the Claim of Susan Decatur and Others, H.R. Rep. 23-522 (1833); Committee on Naval Affairs, On the Claims of the Survivors and Legal Representatives of the Officers and Crew of the Ketch Intrepid, H.R. Rep. No. 24-595 (1836); Committee on Naval Affairs, 
mansion for $\$ 12,000$ to pay off her creditors, ${ }^{54}$ but in 1837 her friends in Congress finally prevailed, securing enough votes for a private act for her relief. ${ }^{55}$ The resulting joint resolution was fashioned as a pension in the amount of $\$ 600$ per year for 5 years and arrearages of nearly $\$ 14,000$, to be administered by the secretary of the treasury as trustee. ${ }^{56}$

One might think that, after 11 years of her seeking relief from Congress, the financial security Decatur had achieved by obtaining a private pension would bring closure to her pursuit. On the same day that Congress passed the joint resolution for Decatur, however, it also enacted a general pension law granting a lifetime pension to every widow of "any officer, seaman, or marine" who died while "in the naval service." 57 In theory, Decatur was also eligible for a pension and substantial arrearages under this unusually broadly worded widows' pension statute which, unlike most traditional war widows' pension statutes, was not restricted to widows whose husbands had died of injuries received in battle. ${ }^{58}$ Never one to shy from asserting her rights, Decatur claimed her private pension from the secretary of the treasury and also applied to the secretary of the navy for a pension under the general law. 59

Decatur's dual applications presented a serious legal quandary. It was true that, at least by the letter of the law, Decatur was entitled to pensions under both the private and public acts. But Secretary of the Navy Mahlon Dickerson would not tolerate double dipping. After seeking the formal

Susan Decatur, H.R. Rep. 34-22 (1856); and Committee on Naval Affairs, Susan Decatur, S. Rep. 34-306 (1856). For representative floor debates, see text accompanying notes 206-210.

54. Harold Donaldson Eberlein \& Cortland Van Dyke Hubbard, Historic Houses of George-Town \& Washington City (Richmond: Dietz Press, 1958), 271.

55. If personal letters sent to Susan Decatur by representatives and senators are to be taken at face value, she had many supporters in Congress. See, for example, File of Susan Decatur, Georgetown University Archives, Box 1, Folder 23, Representative Samuel Carson to Susan Decatur, February 8, 1832; ibid., Box 1, Folder 24, Representative Edward Everett to Susan Decatur, February 26, 1832; ibid., Box 1, Folder 30, Representative John Patton to Susan Decatur, February 5, 1835; ibid., Box 1, Folder 28, Representative George McDuffie to Susan Decatur, February 7, 1835; and ibid., Box 1, Folder 20, Representative Henry Horn to Susan Decatur, December 31, 1851. Lewis Cass, secretary of war from 1831 to 1836, was also supportive of her claim. See ibid., Box 1, Folder 21, Lewis Cass to Susan Decatur, January 2, 1832.

56. A Resolution Granting a Pension to Susan Decatur, Widow of the Late Stephen Decatur, No. 2, 24th Cong., 2nd Sess. (March 3, 1837); and Cong. Globe, 34th Cong., 1st Sess. 1600 (1856).

57. Act of March 3, 1837, ch. 38, § 1, 5 Stat. 180.

58 . The unusually broad reach of the statute was noted in congressional debates leading to its repeal, as discussed in text accompanying notes 214-18.

59. Decatur v. Paulding, 39 U.S. 497, 514 (1840). 
opinion of the attorney general, Dickerson wrote to Decatur personally, informing her that she could choose to collect under the public act or the private act, but not both. ${ }^{60}$ Under protest, and "without . . . waiving her claim to the latter," Decatur chose to receive a pension under the public act, which provided generous arrearages and also carried an annual pension of $\$ 600$ for life (rather than 5 years). ${ }^{61}$

But Decatur did not relent. Hopeful that the appointment of her husband's friend James K. Paulding as secretary of the navy would increase her chances, Decatur renewed her claim under the private act in 1838 . Paulding denied her claim. ${ }^{62}$ Decatur responded with an aggressive and very unusual course: she sued in federal court, seeking a writ of mandamus "to be directed to the said James K. Paulding, Secretary of the Navy of the United States, commanding him, that he shall fully comply with, obey, and execute, the aforesaid resolution of Congress, of the 3d of March, 1837, by paying your petitioner ... the full and entire amount of the aforesaid sum or sums of money, with interest thereon," which, according to her calculation, totaled $\$ 18,597 .{ }^{63}$ Decatur's efforts in federal court were also fruitless. In an opinion by Chief Justice Roger Taney, the Supreme Court found that the duties imposed on the secretary of the navy by congressional acts such as the one that awarded Decatur a private pension were "not mere ministerial duties" but "executive duties." 64 The "interference of the Courts with the performance of the ordinary duties of the executive departments of the government," Taney reasoned, "would be productive of nothing but mischief." 65

For Decatur, such interference with the "duties of the executive departments" would produce substantial income, not mischief. She continued to

60. Transcript of Record in Decatur v. Paulding, 39 U.S. 497 (1840), B. F. Butler to Hon. Mahlon Dickerson, April 11, 1837; and ibid., M. Dickerson to Susan Decatur, April 14, 1837.

61. Cong. Globe, 34th Cong., 1st Sess. 1600 (1856).

62. Decatur, 39 U.S. 498. Paulding had known Stephen Decatur in the 1810s, when they had lived in the same Washington, D.C., boardinghouse. See Ralph M. Aderman and Wayne R. Kime, Advocate for America: The Life of James Kirke Paulding (Selinsgrove, PA: Susquehanna University Press, 2003), 60-61. Paulding, who was a significant literary voice for the Democratic party, also wrote a "Biography of Commodore Decatur," which was published in Analectic Magazine in 1813. Ibid., 349 n.11.

63. Transcript of Record in Decatur v. Paulding, 39 U.S. 497 (1840), Petition to Circuit Court (November 25, 1839), 6; and ibid., Amended Petition (December 14, 1839), 15.

64. Decatur, 39 U.S. 515. For a discussion of the Decatur case and its significance for early nineteenth-century administrative law, see Jerry L. Mashaw, "Administration and 'The Democracy': Administrative Law from Jackson to Lincoln, 1829-1861," Yale Law Journal 117 (2008): 1673-76.

65. Decatur, 39 U.S. 516. 
seek payment of the private pension by petitioning Congress. Her efforts to secure the private pension must have become even more urgent when, in 1841 , Congress took the exceptional step of repealing the general pension law enacted on March 3,1837 - the law that Decatur had elected as the basis of her pension when she was given the choice by Secretary Dickerson. ${ }^{66}$ Congress repealed that general law for reasons only indirectly related to Decatur's case, but the repeal left Decatur pensionless and, if her champions in Congress were to be believed, relatively penniless. ${ }^{67}$ In 1856 , after a failed effort to pursue her case in the newly created Court of Claims and several resubmissions of her petition to Congress, Decatur finally convinced the legislators to reinstate her private pension, but without the substantial arrearages she sought. ${ }^{68}$ She died 4 years later.

\section{B. Catharine Barr}

Catharine Barr was a contemporary of Susan Decatur and she also pursued a pension from the federal government for much of her adult life. ${ }^{69}$ Beyond this similarity, however, Barr and Decatur had little in common. If Decatur's story resonates with aristocratic sensibilities and entitlements, Barr's story illustrates the new world order of military widows' pensions: a broad-scale, relatively equalized system of social provision for widows

66. Act of August 16, 1841, ch. 8, § 1, 5 Stat. 440, 440 (1841).

67. On occasion, Decatur, or at least her supporters in Congress, claimed poverty. See Cong. Globe, 34th Cong., 1st Sess. 1582, 1600 (1856). Others found this assertion implausible given that Decatur had received arrearages of approximately $\$ 14,000$ under the March, 3, 1837 public law before it was repealed. Ibid., 1600. The repeal of the March 3, 1837 general pension law is discussed in detail in section III.C.

68. Joint Resolution for the Benefit of Susan Decatur, Widow of Commodore Stephen Decatur, Late of the United States Navy, S.R. 24, 34th Cong., 1st Sess. (August 2, 1856); and Cong. Globe, 34th Cong., 2nd Sess. 2227 (1856).

69. Starting in 1837, Catharine Barr also pursued a pension for herself and her siblings based on the military service of their father, Andrew Dorgan. Under most traditional war widows' pension statutes, if the widow died or remarried, the pension would go to the children of the deceased officer, soldier, or seaman, until the children reached the age of 16 or, in the case of some navy pensions, 21. See, for example, Act of April 10, 1812, ch. 54, §2, 2 Stat. 704, 704; Act of March 3, 1837, ch. 38, § 1, 5 Stat. 180, 180. In 1837 the children of Andrew Dorgan were awarded pensions for the death of their father in 1817. Although Barr was the primary advocate for the pension, she collected only a one-time payment of $\$ 8.57$ because she had turned 21 years of age 3 months after her father died, whereas her youngest sibling collected a handsome payment of $\$ 1,466.71$. See File of Andrew Dorgan, NARA, Records Department of Veterans' Affairs, RG 15, Old Wars Pension Files, File No. 373, Andrew Dorgan Sailing Master, Dec'd 20 July 1817 (table calculating pensions due children of Andrew Dorgan); and File of Catharine Davidson, NARA, Records of the Department of Veterans' Affairs, RG 15, Old Wars Pension Files, Widow's File 322, Catharine Barr to Secretary of the Navy, February 14, 1842. 
intended primarily as a form of financial support for widows in need, rather than a status-based reward. Barr's experience navigating the pension system was far more typical of the experiences of the thousands of women who sought pensions during this period. Perhaps most significant, her primary (and perhaps only) mode of seeking a pension was not by direct petition to Congress, but by way of an administrative claim filed with pension administrators in Washington, D.C.: low-level bureaucrats in the War Department Pension Office who processed thousands of widows' claims every year. ${ }^{70}$ But Barr's claim was exceptional in one regard: Barr was fully literate, and though she had occasional help, it appears that she represented herself in most of her efforts to secure a pension. ${ }^{71}$ Barr's letters to various administrators therefore provide a fragmented but nevertheless first-person account of her navigation of the federal pension system, and of her personal understanding of widows' pensions and their meaning for women.

Barr was born in 1796 and from her correspondence we learn that she married her "young and Beloved husband" George Bundick when she was 16 or 17 years of age. ${ }^{72}$ From that point forward, however, Barr explained in an 1842 letter to pension administrators, "my prospects in life have been Overcast."73 Bundick was killed in 1814 "in an engagement between an English Brig and the Privateer Schooner Surprise of Baltimore." 74 After his death, and thanks to a series of statutes that made pensions available to War of 1812 widows regardless of their husbands' rank, Barr "received a small [annual] pension of 72-Dollars for five years or as long as I remained his widow." 75 By the time Barr was 18 years old, she was a pensioned widow.

70. For a detailed description of this administrative process, see Collins, "Administering Marriage," 1123-46.

71. The vast majority of widows and veterans were represented by pension claims agents, who took a percentage of the pension as payment for their services. Ibid., 1124-26.

72. File of Catharine Davidson, NARA, Records of the Department of Veterans Affairs, RG 15, Old Wars Pension Files, Widow's File 322, Catharine Barr to Commissioner of Pensions, June 20, 1858; and File of Andrew Dorgan, NARA, Records Department of Veterans' Affairs, RG 15, Old Wars Pension Files, File No. 373, Andrew Dorgan Sailing Master, Dec'd 20 July 1817 (recording Catharine Dorgan's date of birth as October 20, 1796).

73. File of Catharine Davidson, NARA, Records of the Department of Veterans' Affairs, RG 15, Old Wars Pension Files, Widow's File 322, Catharine Barr to Secretary of the Navy, February 14, 1842.

74. Ibid.

75. Ibid. Barr was almost certainly pensioned under the Act of March 4, 1814, which provided for the widows of "any officer, seaman or marine serving on board of any private armed ship or vessel bearing a commission" of the United States. Act of March 4, 1814, ch. $20, \S 1,3$ Stat. $103,103$. 
At this point, there is a significant gap in Barr's account to the pension administrators. She does not tell them how long she collected the pension she received as Bundick's widow, but other records suggest that she married again in $1818,{ }^{76}$ an act that would have terminated her pension, if it had not already expired. Most widows' pensions terminated if and when the widow remarried, under the presumption that the widow would be supported by her husband, and hence no longer needed government assistance. ${ }^{77}$ But Barr's experience demonstrates that, for women, the material security provided by marriage was both contingent and uncertain. By 1823, she appears to have been widowed again, but she was remarried in April of that year to Captain Charles Hobday. ${ }^{78}$ Widowed again and almost 39 years old, in 1835 Barr married a navy quartermaster, William Davidson. ${ }^{79}$ Within 1 year of their marriage, Davidson died in a navy hospital of a "profuse hemorrhage from the lungs" that had developed during one of his voyages. ${ }^{80}$ In 1836 , Barr explained in a letter to the secretary of the navy that Davidson's death "cut me of the little Dependance I had and my health will not allow me to work very hard to support my self." 81 More important for her pension eligibility, there was no doubt that Davidson had died "in the publick service," and hence that his widow was eligible under

76. See Application of Harriet M. Buhler for Membership in the Daughters of the American Revolution, Oct 15, 1937 (listing Catherine [sic] Dorgan's marriage to Samie Sniffen in 1818). Buhler's account is consistent with a contemporary record of Catharine's subsequent marriage to Charles Hobday in 1823. See "Married," N.Y. Spectator, April 29, 1823, 1 (reporting the marriage of Captain Charles Hobday to Mrs. Catherine [sic] Sniffen).

77. See, e.g., Act of March 4, 1814, ch. 20, $§ 1,3$ Stat. 103, 103 ("in the case of death or intermarriage of such widow before the expiration of the term of five years" the remaining pension payments "shall go to the child or children of the deceased" and "shall cease on the death of such child or children"); and Act of June 30, 1834, ch. 134, 4 Stat. 714, 714 ("every pension hereby granted shall cease on the death or marriage of such widow"). Congress sometimes made exceptions to this rule by allowing some re-widowed widows to claim pensions. See discussion in note 182.

78. See "Married," N.Y. Spectator, April 29, 1823, 1 (reporting the marriage of Captain Charles Hobday to Mrs. Catherine [sic] Sniffen).

79. See File of Catharine Davidson, NARA, Records of the Department of Veterans Affairs, RG 15, Old Wars Pension Files, Widow's File 322, Marriage Certificate of William and Catharine Davidson, October 15, 1835. Although it is unclear when Charles Hobday died, an 1829 New York City directory lists Catharine Hobday as a widow. See Longworth's American Almanac, New York Register, and City Directory for the Fifty-fourth Year of American Independence (New York: Thomas Longworth, 1829), 293.

80. File of Catharine Davidson, NARA, Records of the Department of Veterans Affairs, RG 15, Old Wars Pension Files, Widow's File 322, Thomas Williamson to Catharine Davidson, August 14, 1836. Williamson, a hospital administrator, added that Davidson was an "old sailor, of depraved constitution, \& has been a hard drinker." Ibid.

81. Ibid., Catharine Davidson to Secretary of the Navy, August 22, 1836. 
an existing general pension statute. ${ }^{82}$ Pursuant to the Act of June 30, 1834, Barr collected an annual pension of $\$ 72$ following Davidson's death. In March 1837, the 1834 Act was replaced by another general pension statute: an act that awarded navy widows a lifetime pension. ${ }^{83}$ In 1837 or 1838 , Barr began receiving the same modest amount pursuant to the new pension statute, almost certainly the Act of March 3, 1837.84 (Coincidentally, this was the same statute under which Susan Decatur, as the widow of a highranking officer, collected an annual pension of $\$ 600$ and arrearages of nearly $\$ 14,000$.)

In 1840, Catharine married James Barr, thus forfeiting her pension. ${ }^{85}$ Nevertheless, 2 years into her marriage to James, she sought renewal of her widow's pension. "[M]y object," Barr explained, "is to ascertain if in any case you have the power to continue the pension allowed the widow of an Officer or Seaman who dies in the naval service . . ." 86 With no mention of her marriage to James, she explained that "poverty and ill health forces me to turn to my country and ask as a Boon that the pension allowed me at the death of Mr. Davidson may be continued to me a few years that I may enjoy through the liberality of my country a few of the comforts of life wich advancing age and a sickly constitution stand so much in need of." 87

In the final line of the 1842 letter, Barr spoke of a congressional appeal by way of petition: "[T]he clerk of the pension office here promised me he would write for me or send to Congress last session [but] I have not heard that he did owing to some Difficulty on his part at the office." 88 It is not clear whether Barr ever petitioned Congress directly. Had she done so, Barr would have taken a path that was used by many widows, sometimes with success, as discussed in greater detail below. But whatever the form or status of her appeal in 1842, her efforts were unavailing.

In 1858, now approximately 61 years old and writing from Mobile, Alabama, Barr again renewed her quest for a pension, making clear what had been implicit in her 1842 letter to the pension administrators: although Barr had remarried, her husband James had given her little financial

82. Ibid. See also ibid., Pension Certificate of Catharine Davidson, September 2, 1836.

83. Act of March 3, 1837, ch. 38, § 1, 5 Stat. 180.

84. File of Catharine Davidson, NARA, Records of the Department of Veterans Affairs, RG 15, Old Wars Pension Files, Widow's File 322, Catharine Barr to Commissioner of Pensions, June 20, 1868.

85. Ibid., Form of Declaration for Obtaining a Renewal Widow's Navy Pension, September 17, 1868.

86. Ibid., Catharine Barr to Secretary of the Navy, February 14, 1842.

87. Ibid.

88. Ibid. 
support. "[M]y husband has neither been with me or given me one dollar for my support since 1849, and I know not his whereabouts." 89 She added, "I hope sir if possible you will consider all this I am Old now and cannot want a great while longer." ${ }^{90}$ Barr's plea for a pension was both emphatic and desperate: "I think it is no more than right that our Country should allow us that mite for our own Exclusive use and for no other, there are many of us would be thankful for it in our Old age. I for one," she implored, "have no Dependence on Earth only what comes through my relations." "91

Barr's prediction of a precipitous death seems to have been overstated, however, for in the late 1860 s we find Barr back in Brooklyn, making one final attempt to secure the pension she had been awarded based on her brief marriage to William Davidson. She renewed her application to the Pension Office, this time with the help of a pension claims agent, noting that her husband James had died. ${ }^{92}$ But the death of a subsequent husband was not generally grounds for renewal of a pension, and a notation in her file indicates that her efforts were once again fruitless: "Application ... rejected the widow has remarried." 93

Barr's letters to various pension administrators reveal that she, like Decatur, pursued a pension with a kind of tenacity and endurance that may seem surprising to us today. However, although Barr and Decatur were exceptional in many regards, it was fairly typical for widows to pursue pensions over a period of many years, even decades. It is also significant that in her letters, Barr demonstrates her knowledge and consciousness of her rights as a widow, and, in particular, of these rights as they related to the federal pension system. Through her pursuit of a widows' pensionfrom 18 to 71 years of age-Barr acquired a fairly detailed understanding of the inner workings of the pension system's procedures. In 1836, soon after William Davidson died, Barr wrote to the navy hospital seeking a pension, and was promptly directed to the Navy Department and provided with "a newspaper containing the forms necessary in this

89. Ibid., Catharine Barr to Commissioner of Pensions, September 8, 1858.

90. Ibid.

91. Ibid., Catharine Barr to Commissioner of Pensions, June 20, 1858.

92. Ibid., Form of Declaration for Obtaining a Renewal Widow's Navy Pension, September 17, 1868.

93. Ibid., anonymous folder notation, November 7, 1868. Sometimes administrators - or, on appeal, legislators - exercised leniency on this point, allowing widows to collect a pension after they had remarried and were re-widowed, even when the particular widows' pension statute clearly terminated the widow's pension upon remarriage. See discussion in note 182 . 
proceeding." ${ }^{94}$ Eager for her pension, Barr immediately wrote to the Navy Department, providing the necessary evidence and certifications. ${ }^{95}$ Over the years, Barr's letters recorded her familiarity with the various pension statutes, such as the fact that some provided for pensions for life and others for 5-year terms. She knew that remarriage meant an end to any widow's pension, a fact that she especially lamented after her marriage to James Barr. When she asked for her pension to be reinstated despite her remarriage, she understood that she was asking for an exception to the general rule. She also understood that pension administrators were hesitant to create something called "precedent" that another widow might use to support a claim. For a woman of few means and with little assistance, Barr knew a great deal about the operation of the pension laws.

Barr's letters also reveal that she understood the merits and equities of her pension claim in light of her conviction that financial need should, and sometimes did, serve as a justification for government assistance for widows. "I have understood," Barr wrote in 1842, "there was something Extra allowed for those who was killed or wounded in the time of the war, and as I understand you have a kind and generous feeling for the poor of your Country, I have taken the liberty of asking for information from you and I feel in hopes sir you will not deny it." ${ }^{\prime 96}$ Equally notable was that Barr knew that the widows' military pension system favored wealthy women - the Susan Decaturs of the world - and believed that the system should be used to help needy women instead: "When i reflect on the facts that there are many rich in this world ... who receive their pension that can well do without it, when the poor woman who marries to find herself a home and then has to work hard for littel nescisaries she may want, . . . could be allowed to retain our pension I mean the poor like myself for our own use it would be a great comfort as a poor woman cannot expect to marry a rich man ...."97

\section{Widows' Petitions as Legal and Political Process}

Women's petitioning activities in the early nineteenth century are not news to students of the period. We have long known about reform-oriented petitioning campaigns, such as those led by abolitionist and anti-removal

94. File of Catharine Davidson, NARA, Records of the Department of Veterans Affairs, RG 15, Old Wars Pension Files, Widow's File 322, M. G. Delancy to Catharine Davidson, July 27, 1836.

95. Ibid., Catharine Davidson to M. Dickerson, August 29, 1836.

96. Ibid., Catharine Barr to Secretary of the Navy, February 14, 1842.

97. Ibid. 
organizations. ${ }^{98}$ In light of the expansion of white manhood suffrage in the early nineteenth century, however, women's petitions sometimes appear to have operated as a degrading substitute for the ballot. Discursive conventions marked the petition as a political-legal tool of the early modern subject, rather than the modern citizen. As Linda Kerber has suggested with respect to women's petitions of the Revolutionary era, petitioning was a particularly suitable mode of political behavior for women because the petition "begins in the acknowledgement of subordination .... The rhetoric of humility is a necessary part of the petition as a genre, whether or not humility is felt in fact." 99 As a generic form, the petition predates a progressive-liberal tradition in which disgruntled groups declare their rights, a tradition that some American women joined in 1848 with the Declaration of Sentiments and Resolutions. Seen in this light, the experiences of Decatur and Barr would seem to be best understood as individual legal episodes of little significance to the grand arc of women's legal history, or to the emergence of a form of social provision that remains vital in American law and social policy. But a closer look at the evolution of military widows' pensions reveals the centrality of widows' petitions to the development of the first system of centralized public marriage-based entitlements.

Despite the humble conventions of the petition, in the early nineteenth century it provided a means by which individuals could, and regularly did, assert formal claims on the state and federal governments. Men and women petitioned Congress for compensation when the government destroyed their property, or when troops consumed their provisions or livestock. ${ }^{100}$ Disasters both natural and man-made precipitated waves of petitions for emergency relief. ${ }^{101}$ Government officials frequently petitioned Congress for indemnification after being found liable for tortious conduct in the execution of their duties. ${ }^{102}$ Veterans petitioned Congress for pensions and land bounties, ${ }^{103}$ and towns petitioned Congress for postal routes

98. See sources cited in note 10 .

99. Kerber, Women of the Republic, 85. For a wonderful examination of the differences in the rhetorical modes of men's and women's anti-removal petitions, see Portnoy, Their Right to Speak, 71-78.

100. Cynthia A. Kierner, Beyond the Household: Women's Place in the Early South, 1700-1835 (Ithaca, NY: Cornell University Press, 1998), 97-99.

101. See Michele L. Landis, 'Let Me Next Time Be "Tried by Fire"': Disaster Relief and the Origins of the American Welfare State, 1789-1874," Northwestern University Law Review 92 (1998): 978-81.

102. See James E. Pfander and Jonathan L. Hunt, "Public Wrongs and Private Bills: Indemnification and Government Accountability in the Early Republic," New York University Law Review 85 (2010): 1932-39.

103. See Jensen, Patriots, 68-69; and Resch, Suffering Soldiers, 85-91. 
and post offices. ${ }^{104}$ Women petitioned state legislatures for all manner of relief, including divorce, protection of their assets from their husbands' creditors, and recognition of feme sole status for purposes of trading. ${ }^{105}$ On the more altruistic end of the spectrum, women petitioned for recognition and incorporation of benevolent societies, and for appropriations of cash and land subsidies to support the societies' missions. ${ }^{106}$ When widows petitioned Congress for pensions, they engaged in a wellestablished, and presumably well-understood, legal process.

By the 1810s, widows seeking pensions petitioned Congress in two ways. A widow who clearly did not qualify for a pension under one of the general pension laws would often petition directly for a bill for private relief: an individual appropriation. That was Susan Decatur's approach. However, many of the widows who petitioned Congress for a pension had already sought one using the administrative claim procedure that had been established to implement the general pension laws. That was Barr's path to a pension. If a widow's claim was denied by the administrators, she could appeal to Congress by petition-an option used by hundreds of widows, perhaps including Barr. ${ }^{107}$

Regardless of the route to Congress, a widow rarely traveled it alone. A widow such as Decatur received the assistance of a network of men in Congress and the executive branch, ${ }^{108}$ but widows of little means also received significant help from pension claims agents, family members, neighbors, and, occasionally, town officials or groups of supporters. Probably because of the complexities involved in petitioning for a pension and the limited literacy or illiteracy of some petitioners, widows' pension petitions, like veterans' pension petitions of the same period, were often written by another-usually the agent-although they were always

104. See Richard John, Spreading the News: The American Postal System from Franklin to Morse (Cambridge, MA: Harvard University Press, 1995), 49-50.

105. See Kierner, Beyond the Household, 125-27; Cott, The Bonds of Womanhood, 7; see also Ruth Bogin, "Petitioning and the New Moral Economy of Post-Revolutionary America," William \& Mary Quarterly 45 (1988): 391-425.

106. See Suzanne Lebsock, The Free Women of Petersburg: Status and Culture in a Southern Town, 1784-1860 (New York: Norton, 1984), 196-201. At the federal level, from 1848 to 1854 , Dorothea Dix famously petitioned Congress for a land grant with the intention of selling the land to provide relief and support for the poor and insane. See Thomas J. Brown, Dorothea Dix: New England Reformer (Cambridge, MA: Harvard University Press, 1998), 148-214.

107. For a discussion of this appeal process, see Collins, "Administering Marriage," $1129-45$.

108. See, for example, sources cited in note 55. 
necessarily signed or marked by the widow herself. ${ }^{109}$ It would be a mistake, however, to dismiss the widows' involvement in the petitioning process. ${ }^{110}$ Others undoubtedly helped widows, but community involvement with a widow's pension application or petition was also a matter of administrative necessity, as the general pension statutes required that the widow gather written testimony from neighbors and family members who had personal knowledge of particular facts relevant to the widows' eligibility. ${ }^{111}$ Moreover, these petitions usually were not the result of organized collective action of the sort that was obviously behind abolitionist and antiremoval petitions. As discussed below, widows sometimes petitioned in small groups, and those group petitions appear to have been effective in

109. For a useful discussion of various forms of literacy among men and women in this period, and the difficulty of determining literacy rates, see Carl F. Kaestle, "The History of Literacy and the History of Readers," Review of Research in Education 12 (1985): 11-53.

110. One possible theory is that the lion's share of the pressure to enact military widows' pensions came from men-men who risked their lives in war and who were gradually being incorporated into the ranks of the enfranchised. It is clear that men and groups of men sometimes pressed for widows' pensions. See, for example, Committee on Military Affairs, Pamela Adams, H.R. Rep. 23-328, 2-3 (1834) (report reprinting letter signed by 97 men in support of a widow's pension petition); Journal of the House of Representatives 341 (28th Cong., 1st Sess. 1844) (Representative David L. Seymour presenting a resolution of the State of New York urging extension of Revolutionary War widows' pensions); and Journal of the House of Representatives 343 (28th Cong., 1st Sess. 1844) (Representative Jacob Collamer presenting a "Joint Resolution Relative to Pensions to Widows of Revolutionary Officers and Soldiers" on behalf of the Vermont state legislature). However, upon closer analysis this explanation is only partial, and is in certain respects misleading. As an initial matter, many of the military widows' pensions - even for traditional war widows - were granted retroactively, suggesting that men did not routinely insist on widows' pensions as a condition for service. See, for example, Act of March 4, 1814, ch. 20, $\S 11-2,3$ Stat. 103, 103-4; Act of April 16, 1816, ch. 55, $\S \S 1-2,3$ Stat. 285, 285-86; and Act of July 4, 1836, ch. 362, § 1, 5 Stat. 127, 127-28. Moreover, as classes of potential pensioners, veterans and widows were sometimes in direct competition for resources, revealing a misalignment of interests between veterans (at least some of whom were enfranchised) and widows (none of whom were enfranchised). Indeed, in the 1830s, some officers actively petitioned against proposals that would fund officers' widows' pensions from a tax levied on officers' regular pay. See, for example, Memorial of Sundry Officers of the Army and Military Academy Remonstrating Against the Passage of the "Bill to Provide for the Support of Widows and Orphans of Such Officers of the Army as May Die While in Service of the United States," H.R. Rep. 23-74 (1834); Memorial of a Committee of Officers Stationed at Fort Monroe, H.R. Rep. No. 23-130 (1834); Petition Against Bill to Provide for Widows of Officers, H.R. Rep. No. 23-205 (1834); and Remonstrance of Officers of the Army and Military Academy Against Taxing Their Pay for the Support of Widows and Orphans of Deceased Officers, S. Rep. No. 23-563 (1834). In short, although there is no doubt that men-fathers, brothers, adult sons, neighbors, and town officials - had an interest in securing assistance for widows, widows themselves were the most active proponents of widows' pensions.

111. See Collins, “Administering Marriage," 1130-40. 
drawing attention to the merits of widows' claim on the public treasure. However, the vast majority of the widows' pension petitions were submitted by individual widows seeking individual relief.

In short, most widows' pension petitions demonstrate neither heroic individualism navigating the legal system nor reform-style organization. Rather, they are evidence of widows' participation in, and active utilization of, a well-established process of seeking relief and recognition of legal rights, old and new, from the national legislature. ${ }^{12}$ Widows' petitions reflect their understanding - which others shared - that it was right and proper for them to reach out to the federal government for monetary assistance, and that the federal government should provide that assistance. And, as shown below, although widows' petitions were not always successful in the immediate term, collectively and over time these petitions prompted Congress to provide pensions for military widows.

\section{A. Widows on the National Legislative Agenda}

Widows' petitions influenced the legislative development of the military pension system by ensuring that widows' needs - and their claims on the polity - were on Congress's agenda. This may seem like a minor point, but in the world of legislative process agenda setting was a crucial step in the transformation of an idea or a need into a codified, enforceable right or duty. In this respect, the widows had legislative custom and the federal Constitution on their side. Under the First Amendment, widows had a right to petition Congress. That right did not ensure that their petitions would be answered affirmatively, or even that they would be formally "submitted" through congressional procedures, but it undoubtedly imbued national legislators with a felt obligation to consider citizens' petitions, including those from widows. ${ }^{113}$

112. In this regard, the widows' pension petitions and statutes support Barbara Yngvesson's important observation that law "is neither 'from above' nor 'from below' but simultaneously separate and immanent, imposed and participatory." Barbara Yngvesson, "Making Law at the Doorway: The Clerk, the Court, and the Construction of Community in a New England Town," Law \& Society Review 22 (1988): 412.

113. I take no position on whether the First Amendment petition clause obliged Congress, or any other branch of the federal government, to formally consider the petitions it received. Compare Julie M. Spanbauer, "The First Amendment Right to Petition Government for Redress of Grievances: Cut from a Different Cloth," Hastings Constitutional Law Quarterly 21 (1993): 17, with Gary Lawson and Guy Seidman, "Downsizing the Right to Petition," Northwestern University Law Review 93 (1999): 739-40. As a matter of practice, it is almost certain that some widows' petitions were not considered at all. However, the fact that legislators appear to have been generally responsive to widows' pension petitions for individual relief, even if they did not usually act on them affirmatively, suggests that the 
Other aspects of the legislative process affected Congress's response to widows' pension petitions. By the 1810s, Congress had developed several standing committees to investigate the merits of military pension petitions. ${ }^{114}$ Although the membership of committees varied slightly from session to session, ${ }^{115}$ the committee system brought some measure of consistency to the petition review process. A relatively small, stable group of legislators evaluated individual widows' petitions. Thus, Decatur's petitions were vetted by the same subset of legislators who assessed the merits of petitions submitted by widows of lesser means and status.

With this legislative apparatus in mind, one can trace the influence of widows' petitions on the enactment of two important general widows' pension acts in 1836. In March of that year, Congress enacted a general pension statute that altered the status quo with respect to pensions for soldiers' war widows. Prior to 1836 , Congress had received many pension petitions from widows of soldiers and seamen killed in service, ${ }^{116}$ and starting in the 1810s Congress enacted several general pension statutes for the benefit of such widows. ${ }^{117}$ Nevertheless, the default rule remained that only officers' wives were granted pensions if their husbands died in battle. ${ }^{118}$ Then, in 1836 , in a direct response to "a petition in behalf of the widow and children

legal tradition mandating some sort of response was a strong one, indeed. See Gregory A. Mark, "The Vestigial Constitution: The History and Significance of the Right to Petition," Fordham Law Review 66 (1998): 2160 ("The government . . . felt a socio-political obligation to hear those grievances [expressed in petitions], to provide a response, and often to act upon the complaints.").

114. See Norman K. Risjord, "Congress in the Federalist-Republican Era," in Encyclopedia of the American Legislative System, ed. Joel H. Sibley (New York: Scribner, 1994), I:99-109.

115. Ibid., 103 table 2.

116. See, for example, Pension, February 20, 1819, American State Papers: Claims 1: 675 (committee report on the petition of Ruth Reed); On the Claim of the Widow of a Seaman Who Died in Dartmoor Prison, in England, to Five Years' Half-Pay, February 3, 1827, American State Papers: Naval Affairs 3: 24 (committee report on the petition of Abigail Appleton); Committee on Invalid Pensions, Thankful Randall, H.R. Rep. No. 23-89 (1835). Congress also received petitions from officers' widows who, for whatever reason, did not qualify for a pension under the general pension statutes. See, for example, Committee on Pensions, S. Rep. No. 16-72 (1820) (report on the petition of Catharine Shapley); Committee on Military Pensions, Polly Campbell, H.R. Rep. No. 20-232 (1828); and Committee on Naval Affairs, Sophia Gardner, H.R. Rep. 21-113 (1831). See also Army Contractor Killed by the Enemy, February 15, 1804, American State Papers: Claims, 1:297 (committee report on the petition of Ann Elliot).

117. For examples of pre-1836 general pension statutes granting pensions to widows of soldiers killed in battle, see statutes listed in note 19.

118. See The First System of Public Marriage-Based Entitlements (text section I.) 
of Major Dade, Captain G. W. Gardiner, Lieut. Bessinger, and other such widows and children of officers, non-commissioned officers and men," Congress abandoned the piecemeal approach. ${ }^{119}$ Dade, Gardiner, and Bessinger had been killed along with 105 other men in a widely reported battle with the Seminole Indians in Florida. ${ }^{120}$ Petitioners implored Congress "to alleviate their distresses by feeding the widows, and enabling the mothers to feed and educate their children." 121 A lengthy committee report reviewed the long history of awarding pensions to officers' widows as a routine matter but to soldiers' widows on an ad hoc basis only. Invoking and reaffirming the centrality of the citizen-soldier ideal for men and married women's dependence, the report concluded that widows' pensions (for all ranks) "should be permanent . . . as to give a pledge to the citizen soldier, if he dies in the service, his wife and children should not beg their bread." 122 Approximately 2 weeks later, Congress enacted a general pension statute that changed the default rule for the military establishment by providing for widows of "privates," as well as "officers [and] non-commissioned officers" who died in the line of duty. ${ }^{123}$

A similar pattern of petitioning precipitated the enactment of widows' service-based pensions for large classes of aging widows of veterans of the Revolutionary War, also regardless of the veteran's rank. In the late 1820 s, motivated in part by Congress's provision of service-based pensions for Revolutionary War veterans, ${ }^{124}$ the aging widows of Revolutionary War veterans began petitioning Congress in more substantial numbers. Most Revolutionary War widows' petitions were submitted by individual widows seeking individual relief, ${ }^{125}$ but on at least three

119. Committee of Claims, Major Dade, et al.-Pensions to Widows and Children, H.R. Rep. No. 24-415 (1836).

120. See, for example, "Horrid Massacre!," Pittsfield Sun, February 4, 1836, at 2; "Reported Indian Massacre," Portsmouth Journal of Literature and Politics, January 30, 1836, at 3; "Slaughter of a Detachment of U.S. Troops by the Seminoles, on the 28th of December," Connecticut Courant, February 1, 1836, at 2.

121. Committee of Claims, Major Dade, et al.-Pensions to Widows and Children, H.R. Rep. No. 24-415 (1836).

122. Ibid., 3 .

123. Act of March 19, 1836, ch. 44, §§ 1, 5, 5 Stat. 7, 7.

124. Revolutionary War veterans had been awarded need-based service-based pensions in 1818. See Act of March 18, 1818, ch. 19, 3 Stat. 410, 410-11. Over the course of the following decade, the veterans successfully petitioned for the creation of service-based pensions not tied to financial need, codified in the Act of May 15, 1828, ch. 53, 4 Stat. 269, 269-70. For a rich and illuminating discussion of the political forces that helped give rise to veterans' servicebased pensions, see Jensen, Patriots, 62-122.

125. See, for example, Committee on Pensions, S. Rep. No. 21-69 (1830) (report on the petition of Elizabeth Anderson); Committee on Revolutionary Claims, Martha Yeomans, H. R. Rep. No. 21-154 (1830); Committee on Revolutionary Claims, Elizabeth Dandridge, H. 
occasions, small groups of widows petitioned Congress seeking pensions, not just for themselves, but for all widows who had been married to Revolutionary War officers who had survived the war. Two of these petitions were signed by a small group of New England widows, including Caroline Langdon Eustis, Tabitha Tenney, Elizabeth Adams, Lydia Fogg, and Mary Emery. ${ }^{126}$ As the widow of William Eustis, secretary of war under James Madison and governor of Massachusetts, Caroline Eustis was the most socially elite of the signatories, ${ }^{127}$ but correspondence between Eustis and Tenney, another signatory, reveals that Tenney was the organizer and likely the author of the petitions. ${ }^{128}$ In 1801, while living in Washington, D.C., with her husband Representative Samuel Tenney, Tabitha Gilman Tenney wrote the best-selling novel Female Quixotism, Exhibited in the Romantic Opinions and Extravagant Adventures of Dorcasina Sheldon. ${ }^{129}$ Twenty-eight years later, Tenney was a 67-year-old

R. Rep. No. 21-182 (1830); and Committee on Revolutionary Claims, Nancy Davis, H.R. Rep. No. 21-324 (1830).

126. Petition of [Martha] Poor, Elizabeth Adams, Lydia Fogg, Mary Emery, T. Tenney, and Caroline L. Eustis, NARA, Records of the House of Representatives, RG 233, 21st Congress, 1st Session, Committee on Military Pensions, Tray HR21A-G13.1 (Petitions), Folder Wham-Yeomans, printed in Select Committee, Petitions of Widows of Officers of the Revolutionary Army, H.R. Rep. No. 21-4, at 4 (1830); and Memorial of Certain Widows of Revolutionary Officers, January 18, 1830, NARA, Records of the United States Senate, RG 46, Committee on Revolutionary Pensions, file SEN 21A-G13, tray 31B (petition of Caroline Langdon Eustis, T. Tenney, Elizabeth Adams, M[ary] Emery, and Lydia Fogg). The New England widows' first petition was formally presented in the House on February 16, 1829, along with the New Jersey widows' petition described in text accompanying notes 133-35. See Journal of the House of Representatives 289-90 (20th Cong., 2nd Sess. 1829). The New England widows' second petition was presented in the Senate on January 18, 1830. See Journal of the Senate 86 (21st Cong., 1st Sess. 1830). See also note 140 and accompanying text.

127. Petition of Caroline L. Eustis, October 31, 1849, NARA, Records of the United States Senate, RG 46, 32A-H15, Committee on Revolutionary Pensions, Tray 1, Folder 4.

128. See sources cited in below notes $137-39$.

129. Tabitha Gilman Tenney, Female Quixotism, Exhibited in the Romantic Opinions and Extravagant Adventures of Dorcasina Sheldon, 2 vols. (Boston: I. Thomas and E.T. Andrews, 1801). See also Cathy N. Davidson, Revolution and the Word: The Rise of the Novel in America (New York: Oxford University Press, 2004), 280-82. Although Eustis traveled in the most elite circles of American society, all of the widows who signed the petition were from well-established New England families. For example, Samuel Tenney and William Eustis were classmates at Harvard and Tenney later served as a surgeon's mate under Eustis during the war before serving as a surgeon in his own right. Thomas Francis Harrington, The Harvard Medical School: A History, Narrative and Documentary (New York: Lewis Publishing Co., 1905), 1:55, 63. The two men also served in Congress together. The Elizabeth Adams who signed the petition was most likely Elizabeth Parker Adams of Tenney's hometown, Exeter, New Hampshire. Adams was the widow of a Revolutionary War lieutenant, Samuel Adams. File of Elizabeth Adams, NARA, Records 
widow living in Exeter, New Hampshire. If Tenney's novel can be read as a critique of contemporary patriarchal norms, social and legal, that channeled American women into marriage and demoralizing domesticity, ${ }^{130}$ her widows' pension petitions implicitly reaffirmed marriage as key source of women's status in the polity. But whereas Tenney's petitions undoubtedly based the widows' claim to public monies on their marriages to worthy husbands, rhetorically, the petitions emphasized the widows' own wartime contributions. The first petition, submitted in 1829, explained "[ $t]$ hat in the arduous struggle for the Independence of these American States, they shared with their now deceased partners in many of the Perils, and suffered with them in many of the hardships, incident to that . . . period." 131 Noting that "some of " the widows were in "humble circumstances," they sought "the assistance of their country for support."132

The same year, 1829, a small group of widows from New Jersey-Mary Hunter, Susanna Armstrong, Susan Dayton, and Sarah Cumming-also submitted a petition seeking service-based pensions as Revolutionary War widows. ${ }^{133}$ They, too, were widows of officers and they also drew attention to women's wartime suffering and labors as justification for widows" pensions. ${ }^{134}$ Although the widows did not "partake of the dangers

of the Department of Veterans Affairs, RG 15, Series M804, W 20564, Declaration of Elizabeth Adams, August 15, 1838. Adams was related by marriage to Lydia Fogg, as Adams's grandfather, Reverend Jeremiah Fogg, was Lydia's father-in-law. Ibid. Lydia Fogg lived just south of Exeter in Kensington, New Hampshire and was the widow of Jeremiah Fogg, a major in the Revolutionary War. File of Lydia Fogg, NARA, Records of the Department of Veterans Affairs, RG 15, Series M804, W 16116, Declaration of Lydia Fogg, August 15, 1838. Major Fogg was a 1768 graduate of Harvard College and, following the Revolution, a senator in the New Hampshire State Senate. See Jeremiah Fogg, Journal of Major Jeremiah Fogg During the Expedition of Gen. Sullivan in 1779 Against the Western Indians (Exeter, N.H.: The New Letter Press, 1879), 1.

130. Davidson, Revolution and the Word, 278.

131. Petition of [Martha] Poor, Elizabeth Adams, Lydia Fogg, Mary Emery, T. Tenney, and Caroline L. Eustis, NARA, Records of the House of Representatives, RG 233, 21st Congress, 1st Session, Committee on Military Pensions, Tray HR21A-G13.1 (Petitions), Folder Wham-Yeomans.

132. Ibid.

133. Select Committee, Petitions of Widows of Officers of the Revolutionary Army, H.R. Rep. No. 21-4, 3-4 (1830) (printing memorial of widows Mary S. Hunter, Susanna Armstrong, Susan Dayton, and Sarah Cumming); Journal of the House of Representatives 290 (20th Cong., 2nd Sess. 1829) (presentation of memorial of widows Hunter, Armstrong, Dayton, and Cumming).

134. For example, Dayton was the widow of the Revolutionary War general Jonathan Dayton, who was a high-ranking Federalist until he was arrested for treason in 1807 for his alleged role in the Burr Conspiracy. New International Encyclopedia, 2nd ed. (New York: Dodd, Mead, 1914), 6:548. Sarah Cumming was the widow of John N. Cumming, a colonel in the Continental Army. File of Sarah Cumming, NARA, 
and hardships and privations of their husbands," they explained, "it was their lot to endure constantly the far more exquisite pains which the heart of woman feels when he to whom she is connected by the nearest and most tender ties is engaged in battle ...."135

Despite these particular widows' relative access to power, neither of these petitions resulted in a private act for any of the petitioning widows, nor did they result in an immediate change to the general pension laws. In 1829, the House voted in favor of a bill that would have provided pensions to "each surviving widow who was, at the close of the Revolutionary war, the lawful wife of a[n] . . . officer, musician, or private of said war," but the bill never made it out of the Senate. ${ }^{136}$

Undeterred by her first petition's failure, Tabitha Tenney tried again. In November 1829, Tenney wrote to Caroline Eustis soliciting her signature on a second pension petition. In the letter, Tenney described the fate of the first petition "she caused . . . to be written . . . in behalf of most of the surviving widows of the officers of the revolutionary war"137 and then declared her resolve. "I am now determined to make another attempt, $\&$ I inclose a petition for your signature, if you judge proper to join me in it." ${ }^{138}$ Eustis obliged and sent the signed petition back to Tenney. Tenney gathered the signatures of all but one of the widows who had signed the first petition and then, several weeks later, wrote to Eustis seeking additional help. Confessing that she "ha[s] now scarcely a single acquaintance in either house," as it had been "so long since my husband was in Congress," Tenney asked Eustis to use her connections in Congress to ensure that the petition was presented effectively: "[U]pon the supposition that you have among the members a number of friends \& acquaintances, I

Records of the Department of Veterans Affairs, RG 15, Series M804, W 7234, Declaration of Sarah Cumming, October 21, 1836. Susanna Armstrong was the widow of the Reverend James Armstrong, who graduated from the College of New Jersey (which was later renamed Princeton) and served as a trustee in the 1790s. See John Maclean, History of the College of New Jersey from Its Origin in 1746 to the Commencement of 1854 (Philadelphia: J.B. Lippincott, 1877), 2:110.

135. Select Committee, Petitions of Widows of Officers of the Revolutionary Army, H.R. Rep. No. 21-4, 3 (1830).

136. H.R. 405, 20th Cong. 2nd Sess. (1829); Journal of the House of Representatives 328 (20th Cong., 2nd Sess. 1829).

137. T. Tenney to Caroline Langdon Eustis, November 17, 1829, NARA, Records of the United States Senate, RG 46, Committee on Revolutionary Pensions, file SEN 21A-G13, tray $31 \mathrm{~B}$. Given that the petition appears to have been physically penned by a scrivener, it is not clear whether Tenney's assertion that she "caused" the petition "to be written" means that she composed the petition but then had it transcribed, or that she enlisted the services of a pension claims agent, lawyer, or other acquaintance to compose the petition.

138. Ibid. 
have judged it best to send the petition again to you \& request you forward it to some member of the house who is capable of speaking \& of informing our claim."139 Tenney suggested that Eustis enlist the help of Massachusetts senator Daniel Webster. A few weeks later, on January 18, 1830, Webster formally presented the New England widows' second petition in the Senate. ${ }^{140}$ Despite Eustis's connections and Tenney's determined efforts, however, their second petition also failed to yield an immediate result.

Although Congress did not grant these widows' petitions, it would be wrong to conclude that the petitions were ineffectual. All three of these group petitions - as well as a raft of individual widows' petitions-drew national lawmakers' attention to the claims of Revolutionary War widows and inaugurated a process that, within a few years, resulted in the creation of service-based pensions for large classes of aging widows. Committee reports issued on Revolutionary War widows' pension petitions of the early 1830 s reveal legislators' hesitance to continue providing ad hoc private relief for widows, and their inclination to provide broad-scale, systematic relief instead. For example, a committee report issued on the New England widows' second petition recommended against acting on it because the committee members could not "consider this case as embraced within the meaning of any of the [general] pension acts." 141 However, the report was not without hope, noting that "the case of the petitioners presents a very strong and powerful appeal to the justice of the Government." 142 Three years later, the petition of the Revolutionary War widow Anne Royall-another widow with significant connections in Washington ${ }^{143}$ - prompted the House Committee on Military Affairs to state that, "frankly . . . while they cannot recommend a special law for any particular widow of a particular officer," nevertheless it was "worthy of the most serious consideration whether a general provision ought not

139. Ibid. (emphasis in original).

140. Journal of the Senate 86 (21st Cong., 1st Sess. 1830).

141. Committee on Pensions, Report, S. Rep. No. 21-70 (1830).

142. Ibid. In rejecting the pension petition of Celestine Wilkinson, the widow of Brigadier General James Wilkinson, the Senate Committee on Pensions explained that "[i]t has not been the policy of this Government to adopt the system of granting pensions for military services merely." Committee on Pensions, S. Rep. No. 21-71 (1830) (report on the petition of Celestine Wilkinson).

143. Anne Royall was the widow of William Royall, who was a major in the Revolutionary War. Her quest for a pension may have been what brought her to Washington, D.C., in 1824, where she established herself as the first professional woman journalist in America. See Bessie Rowland James, Anne Royall's U.S.A (New Brunswick, NJ: Rutgers University Press, 1972), 104-14. 
to be made for all the surviving widows ... of the revolution." 144 The petitions submitted by widows such as Eustis and Royall-well connected in Washington's world of patronage-were considered along with the petitions of widows of lesser means and status. ${ }^{145}$ Together, these widows' petitions focused Congress's attention on the issue of service-based pensions for aging widows of the Revolutionary War.

In July 1836, in response to "several petitions, memorials, and resolutions" by widows seeking service-based pensions, the House Committee on Revolutionary Pensions returned a favorable report, concluding that "the wives of those persons engaged in the revolutionary struggle" were "entitled" to pensions. ${ }^{146}$ This report picked up the logic of petitions such as those submitted by the New England and New Jersey widows, which called attention to women's wartime work and privations. When men left for the battlefield, the report explained, "the labors of the hardier sex devolved upon females, and the services and sufferings were, in very many instances, equally shared." 147 The report continued, "It is rightly urged that the wife has an interest in her husband's services, and her claim to partake of the recompense will not be denied."148 On July 4, 1836, Congress took the significant step of enacting a general pension law for widows of Revolutionary War veterans-from high-ranking officers to privates - who had married their husbands prior to or during the war. ${ }^{149}$

144. Committee on Military Affairs, Anne Royall, H.R. Rep. No. 23-100 (1833).

145. See, for example, sources cited in note 125 .

146. See Committee on Revolutionary Pensions, Revolutionary Pensions, H.R. Rep. No. 24-210, at 2-3 (1836).

147. Ibid., 3. The committee's focus on wives' wartime contributions supported its recommendation to limit pensions to those widows "whose marriage occurred previous to the expiration of [their husband's] service." Ibid., 2. The notion that pensions for Revolutionary War widows were justified, in significant part, by the widows' service to country and husband was articulated in several congressional reports. In 1839, the House Committee on Revolutionary War Pensions explained that "the wives of our revolutionary patriots, upon whom devolved the whole management of the domestic concerns of the family, during the absence of the husband . . . had much of the troubles, the anxieties, and dangers of the revolutionary struggle to encounter, all will admit." Committee on Revolutionary Pensions, Margaret Wade, H.R. Rep. No. 25-309 (1839). An 1848 House Committee Report provides a similar explanation of the Act of July 4, 1836, noting that the act "was passed, in order to provide for those venerable widows who had shared with their husbands in the sufferings and toils of the revolution." Committee on Revolutionary Pensions, H.R. Rep. No. 31-295, 2 (1848).

148. Committee on Revolutionary Pensions, Revolutionary Pensions, H.R. Rep. No. 24-210, 3 (1836).

149. Act of July 4, 1836, ch. 362, § 3, 5 Stat. 127, 128. For details of the operation of Section 3 of the July 4, 1836 statute, see discussion in note 24 . 
Once Congress had enacted a general pension law, eligible widows applied for pensions using an involved procedure administered by the Pension Office, which was first housed in the Department of War and then, starting in 1849, in the Department of the Interior. But the delegation of such determinations to administrative agencies did not stanch the flow of widows' petitions to Congress. Widows, usually acting individually, continued to petition Congress for material support, either directly or by way of an appeal from the Pension Office. The number of widows' pension petitions varied significantly from Congress to Congress. For example, during the Twenty-First Congress (1829-1831) national legislators entertained the pension petitions of at least 78 widows; during the Twenty-Fifth Congress (1837-1839) they considered at least 424 widows' pension petitions; during the Twenty-Sixth Congress (1839-1841) they considered approximately 396 widows' pension petitions; and during the Thirty-First Congress (1849-1851), they considered at least 182 widows' pension petitions. ${ }^{150}$ Despite the ebb and flow, widows' petitions were a constant feature of Congress's agenda, especially in the 1830 s and 1840 s.

Widows' petitions prompted Congress repeatedly to reconsider the lines it had drawn between the eligible and the ineligible. ${ }^{151}$ In 1839, the House

150. These numbers are estimates based on references in the Senate and House journals to widows' pension petitions formally submitted to and considered by Congress, and in related bills and reports. This information was compiled using the text-searchable online versions of the journals on the Library of Congress American Memory website http://memory.loc.gov/ ammem/hlawquery.html (last accessed September 29, 2011). After gathering references to the term "widow" and recording all references to widows' petitions, I then collected bills and committee reports associated with each widow's name to determine whether, in fact, the widow sought a pension (rather than some other form of relief from Congress). When in doubt, I omitted the widow's petition from the count. A similar search was performed in the "Bills and Resolutions" database on the Library of Congress website and the information similarly crosschecked against other sources. This method is by no means perfect, but neither are the alternatives. On the one hand, relying on digitized records likely leads to underestimation of the number of widows' petitions submitted to Congress, as technological limitations almost surely prevent retrieval of all references to widows' pension petitions, even with careful searching. On the other hand, my experience in the National Archives suggests that many actual petitions have been lost or misfiled, making those records an imperfect source as well. Cross-checks of existing registers of petitions to Congress from and of this period also reveal significant omissions. Finally, there is a problem that riddles any effort to determine how many widows petitioned Congress for pensions during this period: it is far from clear that every petition received by a representative or senator was formally submitted to Congress. As per routine practice, any petition not submitted to Congress by the end of a legislative session was returned to the petitioner. Kenneth Kato, Archives Specialist, Center for Legislative Archives, NARA, Washington, D.C., telephone interview with the author, April 13, 2010.

151. See, for example, Committee on Revolutionary Claims, Ann Mortimer Barron, H. R. Rep. No. 23-58 (1833) (navy widow seeking benefit of army widows' pension statute); Committee on Revolutionary Pensions, Jerusha Ripley, H.R. Rep. No. 24-77 (1837) (widow 
Committee on Revolutionary Pensions reported on the petition of Margaret Wade. The service-based widows' pensions provided by the July 4, 1836 Act were available only to widows who had married a Revolutionary War officer or soldier "before the expiration of the last period of his service." 152 In 1837, Congress extended that Act to include all Revolutionary War widows who had married a soldier or veteran prior to January 1, 1794. ${ }^{153}$ Widow Wade had married a Revolutionary War veteran in June 1794, only 6 months after the cutoff date. The Committee could articulate no principled distinction, and instead declared that "the committee think the distinction . . . invidious and unjust."154

Widow Wade's petition did not yield a direct legislative response or result in a pension. As was often the case, lawmakers were hesitant to "legislate for any particular cases," 155 but as early as 1837 they had expressed "confidence that, by some general provision, the benefits of the [1836] act ... will be extended so as to embrace the cases of all persons who are now the widows of those who served in the revolutionary war."156 They were right. Over the years, the pressure of petitions such as Widow Wade's pushed Congress to expand eligibility criteria, resulting in a steady enlargement of the scope of the July 4, 1836 Act. By 1853, virtually any woman who had ever been married to a Revolutionary War veteran was eligible for a service-based pension. ${ }^{157}$ The result: in the early nineteenth century, tens of thousands of widows were placed on the federal pension rolls.

\section{B. Leveling Up: Every Widow's Pension}

Although it is evident that widows' petitions put widows' pensions on the legislative agenda, this alone cannot explain why, slowly but surely, Congress responded to widows' petitions through the enactment of general pension statutes for large classes of widows. It is also not enough to observe that early nineteenth-century widows' pensions resembled relief

petitions Congress for pension despite the fact that she had remarried); and Committee on Revolutionary Pensions, Hannah Eldridge, H.R. Rep. No. 24-124 (1837) (widow petitions Congress seeking pension despite the fact that she had remarried).

152. Act of July 4, 1836, ch. 362, § 3, 5 Stat. 127, 128.

153. See Act of July 7, 1837, ch. 189, § 2, 5 Stat. 303, 303.

154. See Committee on Revolutionary Pensions, Margaret Wade, H.R. Rep. No. 25-309, $1-2(1839)$.

155. Committee on Pensions, S. Rep No. 24-146 (1837) (report on the petition of Sarah Rogers).

156. Ibid.

157. See sources cited in note 26. 
provided by a growing number of charitable organizations and societies to widows and children in the same period. ${ }^{158}$ Certainly, widows' pensions and charitable relief were born of a similar benevolence, and legislators frequently used the language of charity when describing widows' pensions; however, military widows' pensions were not charity. The pension statutes created legal entitlements - rights - for widows to be paid out of the public coffers. And in this regard, military widows' pensions should be understood as part of a larger shift in the early nineteenth-century American legal landscape: the significant expansion of the social welfare function of marriage.

Under the doctrine of coverture, marriage stripped women of many of their property rights, thus usually leaving them disempowered financially during marriage, and often in dire straits if they were widowed. ${ }^{159}$ Traditional marriage law and related legal doctrines attempted to compensate for married women's legal disabilities by enabling or requiring the husband, or his estate, to provide a modicum of financial support for the wife or widow. For example, under the doctrine of necessaries, a husband could be held liable for essentials, such as food and clothing, purchased by his wife on credit. ${ }^{160}$ Dower, the widow's right to one third of her husband's real property, had long provided limited financial resources for widows of propertied husbands. ${ }^{161}$ In addition, fathers and husbands of means sometimes used trusts or separate estates to insulate their daughters and wives from the harshest consequences of marital property laws. ${ }^{162}$

In the early nineteenth century, however, as America's economy became increasingly industrialized and dominated by commercial markets, it became evident that whatever financial protections these traditional legal devices had provided for married women, they were inadequate during both marriage and widowhood. Industrial accidents claimed the lives of

158. See Lori D. Ginzberg, Women and the Work of Benevolence: Morality, Politics and Class in the Nineteenth-Century United States (New Haven: Yale University Press, 1990); Ronald G. Walters, American Reformers, 1815-1860 (New York: Hill and Wang, 1978); and Anne M. Boylan, "Women in Groups: An Analysis of Women's Benevolent Organizations in New York and Boston, 1797-1840," Journal of American History 71 (1984): 497-523.

159. See Alexander Keyssar, "Widowhood in Eighteenth-Century Massachusetts: A Problem in the History of the Family," Perspectives in American History 8 (1974): 112.

160. See Tapping Reeve, The Law of Baron and Femme, of Parent and Child, Guardian and Ward, Master and Servant, and of the Powers of Courts of Chancery (New York: Banks, Gould, 1841): 80-81.

161. In the majority of American jurisdictions, dower was limited to one-third of the husband's real property, though there was some regional variation on this and other aspects of dower law. See Marylynn Salmon, Women and the Law of Property in Early America (Chapel Hill: University of North Carolina Press, 1986), 147-84.

162. See ibid., 88-89. 
husband-breadwinners, leaving their widows and children with little in the way of tangible assets for support. ${ }^{163}$ For a host of reasons, in the first half of the nineteenth century, dower began waning as a source of support even for the women whose interests it had generally served. ${ }^{164}$ And the doctrine of necessaries, never a particularly robust source of economic stability for wives, did nothing to protect family assets - and married women and their children - from a husband's creditors, whether the husband was alive or dead.

In the early nineteenth century, several other, newer legal devices emerged that were intended, in part, to provide financial protection for a much broader category of married and widowed women, while leaving the basic principles of coverture intact. Several state legislatures enacted intestacy provisions that gave widows an "elective share" of their deceased husbands' assets (both real and chattel property), rather than the traditional promise of dower. ${ }^{165}$ From the 1830 s onward, state legislatures also enacted married women's property acts. At this early stage, these acts served as a kind of quasi-bankruptcy protection for families by shielding a wife's assets from her husband's creditors. ${ }^{166}$ Married women's property acts thus made available to wives of all classes a measure of protection that, until that time, had generally been available only to wealthy wives and families that had the sophistication and means to create legally enforceable separate estates. ${ }^{167}$ In the 1840 s, many state legislatures enacted statutes intended to facilitate the growth of private life insurance- the goal of which was to protect widows and orphans from financial calamity - by loosening coverture-based restrictions on a married woman's ability to contract for insurance on her husband's life. ${ }^{168}$ In the same decade, state

163. See John Fabian Witt, The Accidental Republic: Crippled Workingmen, Destitute Widows, and the Remaking of American Law (Cambridge, MA: Harvard University Press, 2005), 23-26.

164. For a probing discussion of dower, its shortcomings as a means of securing widows' financial stability, and dower reform statutes of the early twentieth century, see Dubler, "In the Shadow of Marriage," 1660-1700.

165. See Richard H. Chused, "Married Women's Property Law: 1800-1850," Georgetown Law Journal 71 (1983): 1394-95.

166. See ibid., 1398-1404.

167. See ibid., 1410.

168. Sharon Ann Murphy, Investing in Life: Insurance in Antebellum America (Baltimore, MD: Johns Hopkins University Press, 2010), 143-48. According to Murphy, "[m]en supported this moderate expansion of the rights of women because it allowed the paternalism of the husband to extend from beyond the grave." Ibid., 151. See also Mary L. Heen, "From Coverture to Contract: Engendering Insurance on Lives," Yale Journal of Law \& Feminism 23 (2011): 346-50; Susanna L. Blumenthal, "Death by His Own Hand": Accounting for Suicide in Nineteenth-Century Life Insurance Litigation, in Subjects of Responsibility: Framing Personhood in Modern Bureaucracies, ed. Andrew Parker, 
legislatures also began to enact homestead exemption statutes, which protected the family home from creditors. ${ }^{169}$ These legal developments expanded the social welfare function of marriage by protecting family assets from the risk of industrial and financial calamity that seemed to have become an inherent part of American life.

Animated by similar concerns, developments in tort law took the social welfare function of marriage one step further by creating the possibility of third-party liability for widows' material support. As John Witt has shown, starting in the 1840 s, state legislatures enacted the first wrongful-death statutes that provided a cause of action for widows of men killed in accidents. ${ }^{170}$ This new claim gradually replaced the common law rule that had allowed the master to sue for the loss of services of a household dependent, but had not allowed a dependent, including a widow, to sue for the loss of support upon the husband-masters' death. ${ }^{171}$ The wrongful-death statutes that replaced the "loss of services" model were decidedly gender based, as they provided a tort remedy for widows but not for widowers. ${ }^{172}$ Significantly, these statutes provided for widows not by shielding existing family assets, but by requiring tortfeasors, especially industrial employers, to pay damages. As a consequence, developments in tort law helped to ensure a baseline financial security for a class of women for whom it had generally provided very little: the widows of workingmen, for whom legal protections of family assets were generally ineffectual, as such women's families had few, if any, assets to protect. ${ }^{173}$

There is no direct relationship or perfect parallel among these various doctrinal developments, but all of them provided for the material interests of a significantly larger class of women than had previously been the case,

Austin Sarat, and Martna Merrill Umphrey (New York: Fordham University Press, 2011): 98-144.

169. See Alison Morantz, "There's No Place Like Home: Homestead Exemption and Judicial Constructions of Family in Nineteenth-Century America," Law \& History Review 24 (2006): 252-54.

170. See John Fabian Witt, "From Loss of Services to Loss of Support: The Wrongful Death Statutes, the Origins of Modern Tort Law, and the Making of the NineteenthCentury Family," Law \& Social Inquiry 25 (2000): 733-43.

171. Ibid., 732 ("[W] hat is remarkable about early actions to recover damages for wrongful death is that ... they all revolved around masters, husbands, or fathers suing to recover damages for the loss of the services of a servant, wife, or minor child.").

172. Ibid., 736-37.

173. A claim to dower was not particularly valuable to women whose husbands lacked property. And unlike women of means, the widows of working men were also unlikely to have any independent resources held in trust for their benefit, Salmon, Women and the Law of Property, 83, or even to benefit from other emerging legal tools, such as the married women's property acts. 
and did so by attaching new legal rights and liabilities to marriage. It bears emphasizing, moreover, that even as these various doctrines expanded the legal rights of widows, they did not challenge coverture or its ideological precepts concerning women's status within the marital relationship or in society. To the contrary, all of these doctrines and legal entitlements built on and reinforced increasingly prevalent gender-based social norms: men's role as the breadwinner, and women's role as the domestic helpmate.

Military widows' pensions were part of this trend, and extended it one step further. Changes to intestacy, property, contract, and tort affected the liabilities and rights of private parties, but widows' military pension statutes recognized public liability for the support of a significant class of widows. Unsurprisingly, some legislators were skeptical of the notion that a widow's legal dependence on a deceased veteran warranted public liability for her support. As an initial matter, some legislators believed that most military pension statutes were unconstitutional, including veterans' service-based pension statutes and widows' pension statutes. ${ }^{174}$ When confronting such resistance, veterans seeking pensions during this period could at least point to their service to the nation as a basis for the country's "debt" for their support. ${ }^{175}$ Widows had a more difficult task because, at least according to some legislators, marriage to a military man was, or should have been, sufficient to provide for a wife's or widow's material needs. In 1843, Senator George McDuffie of South Carolina queried "upon what principle of policy or justice a claim could be set up by a widow, ... . unless it were to be shown that she had participated in the struggle, and had been subjected to the privations incident to the time." 176 In the face of such logic, it was not enough for widows to assert their legal dependency as justification for a pension. They needed to

174. See 31 Annals of Cong. 148 (1818) (statement of Senator William Smith) (contending that creation of veterans' service-based pensions violated the "written Constitution"); and Committee on Revolutionary Pensions, Revolutionary Pensions, H.R. Rep. No. 24-210, 3 (1836) (noting that the military pension system "is condemned by many, as unconstitutional ....”). National legislators also frequently resorted to the Constitution as a basis for opposing private relief bills submitted by widows of high-ranking elected officials, such as Anna Harrison, widow of President William Hamson. See, for example, Cong. Globe, 27th Cong., 1st Sess. 104-5 (1841) (statement of Senator Thomas Benton); Cong. Globe, 27th Cong., 1st Sess. 118 (1841) (statement of Senator Ambrose Sevier).

175. As both Jensen and Resch have demonstrated, many legislators argued that military service alone was not a sufficient basis for a pension. For searching discussions of the veterans' arguments - and resistance to those arguments - see Jensen, Patriots, 63-109, and Resch, Suffering Soldiers, 84-118.

176. Cong. Globe, 27th Cong., 3rd Sess. 388 (1843). See also sources cited in above note 147. 
explain how their role as domestic helpmate of a man who served the country in battle warranted government support.

This may explain why, even as widows drew attention to their husbands' services as a basis for their claims, they also used their petitions to provide legislators with firsthand testimonies of women's own services to country and husband, and of the poverty that frequently befell widows. We see this in the petitions of relatively high-status widows, such as the New England and New Jersey widows, which emphasized the widows' services, and it resonates throughout the pension petitions of common women. Widows seeking pensions often noted the service they performed and the costs they incurred raising their children. The plea that Congress should "enable the mothers to feed and educate their children" 177 was commonplace in petitions submitted by younger widows, but older widows also reasoned that their earlier services as mothers justified a widow's pension in old age. Two decades after her husband's death in the War of 1812, Thankful Randall sought his pension, in part on the grounds that she had born "the expense of bringing up the children, and she is meritoriously entitled to [her deceased husband's] half-pay."178 Similarly, in 1840, Frances Barr petitioned Congress for "remuneration," explaining "that her late husband was a soldier in the late war with Great Britain, and during his absence of three years and seven months, she was compelled to support four children by her own labor." 179 And at 72 years of age, Hannah Duboise petitioned Congress, explaining that after her husband died in the War of 1812 she had supported her two small children, but now she "cannot support herself any longer, and asks for relief from her country." 180 Citing a supporting declaration from her town's overseer of the poor, the committee recommended that Congress grant Duboise's request. 181

Widows - those with and without children - also did not hesitate to argue that their poverty was caused by women's particular vulnerabilities in and out of marriage. In an 1824 petition, Nancy Lancy was candid about women's dependency on their husbands for financial support, and

177. Committee of Claims, Major Dade, et al.-Pensions to Widows and Children, H.R. Rep. No. 24-415, 1 (1836).

178. Committee on Invalid Pensions, Mem[orandum] in Case of Thankful Randall, H.R. Rep. No. 29, NARA, Records of the House of Representatives, RG 233, 24th Congress, Committee Papers - Committee on Invalid Pensions, Hr27a-G9.1 (file of Issac Pishon); see also Committee on Invalid Pensions, Thankful Randall, H.R. Rep. No. 23-89 (1835).

179. Journal of the House of Representatives 939 (26th Cong., 1st Sess. 1840).

180. Committee on Invalid Pensions, Widow Hannah Duboise, H.R. Rep. No. 28-482 (1844).

181. Ibid. 
widows' limited options for self-support. Lancy's husband had died in the War of 1812. She was awarded a pension in 1816, which was then extended in $1819 . .^{182}$ In the early 1820 s, anticipating the expiration of her pension, and "intirely ignorant that it would be extended a second period, she married a man who she calculated would support her."183 Unfortunately for Lancy, he was "soon after lost at sea, having lived with your petitioner only eight days. She is now left depressed with poverty, and afflicted with very slender health, and is, she humbly hopes, as much an object of the protecting care of the Government, as when her first husband fell in defending his country's flag."184

Such pathetic pleas drew on the contemporary trope of the "poor widow" and became part of the generic convention of the widows' petition. But the commonplace nature of widows' pleas of poverty should not diminish their significance. In a world in which military widows' pensions traditionally had been a class-salient form of reward for widows of officers presumptively engaged in heroic service, widows' pleas of poverty collectively reflected and informed a new way of reasoning about widows' entitlement to government relief, and about widows' particular vulnerability to poverty. In this respect, widows' pension petitions helped prompt a shift from treating military widows' pensions as "inducements" for heroic

182. File of Nancy Lancy, NARA, Records of the Department of Veterans Affairs, RG 15, Old Wars Pension Files, Widow's File 688, Pension Certificate, March 4, 1816; ibid., Petition of Nancy Lancy, March 1, 1824. Congress struggled to fashion a pension system that took account of the plight of the re-widowed. For the elderly widows of the Revolutionary War, Congress in 1837 softened the remarriage bar to pensions and allowed pensions for widows of veterans who had remarried but found themselves widowed a second (or third) time. See Act of March 3, 1837, ch. 42, § 1, 5 Stat. 187, 187 (1837). Congress sometimes used private acts to circumvent similar limitations on traditional war widows' pensions. For example, prior to remarrying, the widow of Robert Brice had received a pension for 10 years. Her pension ceased when she married Aaron Bowen, but when Bowen died in 1848, Nancy Bowen petitioned Congress for a pension, as she had been left "in a destitute and helpless situation, aged, infirm, and childless." The Senate Committee on Pensions found that "it is just and proper in cases like this, where the widow has been left in a destitute and helpless condition, to renew the pension." Committee on Pensions, S. Rep. No. 32-93 (1852) (report on petition of Nancy Bowen). A later report on Bowen's petition discussed other similarly situated widows and explained that "this class of petitioners . . . ha[s] been, and will continue to be, provided for by special acts of Congress." See Committee on Pensions, S. Rep. No. 33-242 (1854) (report on the petition of Nancy Bowen). Despite these assertions many traditional war widows who remarried and were re-widowed found themselves unable to convince the Pension Office that they should be re-pensioned. See sources in note 77.

183. File of Nancy Lancy, NARA, Records of the Department of Veterans' Affairs, RG 15, Old Wars Pension Files, Widow's File 688, Petition of Nancy Lancy, March 1, 1824.

184. Ibid. 
military service to "charity . . . extended to the bereaved widow[s]." 185 That shift was significant in its own right, as it reflected an emerging way of reasoning about poverty as a legitimate basis for public expenditure and, as a consequence, helped precipitate the extension of widows' pensions to common women.

We hear the resonance of common women's petitions in legislative debates held in 1818, during a period of substantial leveling and expansion of traditional war widows' pensions. 186 "Equality, in the contributions for the public service, is one of the first principles of our Government," explained Representative (and future President) William Harrison of Ohio in support of a bill that would have extended the duration of War of 1812 widows' pensions. 187 "The public burdens are to fall equally upon all in proportion to their means. No individual, and no family, are to furnish more than their just share, either of money or of personal service, without an equivalent." 188 To underscore this point, Harrison imagined a horde of petitioning widows marching on Washington, children in tow:

Suppose the many hundred widows and orphans, the relicts of the late war, were to be brought before us .... The thing cannot be-but I beg gentlemen to give some scope to their imaginations, and persuade themselves that they really see it. Here a venerable matron, followed by a large family of children; there, another, in the full bloom of beauty, a widow through choice and under a sacred vow that the hero who had once filled her arms should never be supplied by another; the lovely boy she holds by the hand was an orphan before he saw the light .... ${ }^{189}$

Earlier that year, Representative Richard Johnson of Kentucky had employed a similar rhetorical device in support of a bill that would have extended the duration of an existing widows' pension statute. "Bring this unfortunate groupe in review before us; let the image, not of imaginary

185. Committee on Pensions and Revolutionary Claims, Petition Granted to the Widow of a Captain in the Army Who Died in Service, H.R. Rep. No. 14-285 (1816) (report on the petition of Elizabeth Morgan).

186. See, for example, Act of March 4, 1814, ch. 20, § 2, 2 Stat. 103, 103-4 (granting pensions to widows of any "officer, seaman, or marine" of the United States navy who "shall die . . by reason of a wound received in the line of his duty"); Act of April 16, 1818 , ch. $65, \S 1,3$ Stat. 427, 427-78 (granting 5-year extension of pensions awarded to widows pursuant to the Act of March 4, 1814); Act of April 20, 1818, ch. 101, §§ 1-2, 3 Stat. 459, 459 (granting 5-year half-pay pensions to widows of militia who "prosecut[ed] the war against the Seminole tribe of Indians"); and Act of March 3, 1819, ch. 60, 3 Stat. 502, 502 (granting 5-year extension of pensions awarded to widows of "officers, seamen, and marines" killed in the War of 1812).

187. 33 Annals of Cong. 378 (1818).

188. Ibid.

189. Ibid., 382-83. 
but of real bereavement, and consequent distress, be drawn in its full magnitude before our eyes. Behold fourteen hundred and fifty-four weeping widows, and more than a thousand helpless orphans, in all the despondency of wo ...." 190 Johnson then provocatively suggested that the "destitute female, the widow, would have to languish and die, or, by seeking the bounty of the world, must subject herself to insults, and, in many cases it would lead to more disastrous consequences."191

For Johnson and Harrison, the injustice of the current system lay not only in the failure to provide for widows whose husbands had "sacrificed their all" to the country, and who were frequently left in pinching poverty. The system already pensioned widows of officers, or, worse, allowed men of means to escape military service entirely, creating a system of privileged citizenship for wealthy men and their families that was decidedly unrepublican. The "rich married man," explained Harrison, "is allowed to furnish a substitute - the poor married man, unable to hire one, is obliged when called upon to serve in person. As the poor, then, fight all your battles, which is, perhaps, unavoidable, it is just and right the consequences of their service should fall as lightly as possible on their families."192

Harrison's speech was part of an ongoing debate over the propriety of the military pension system more generally. Efforts to expand the federal pension system frequently met with the objection that government-funded relief was inappropriate in a republic. Opponents argued that military pensions would lead to a class of aristocratic placemen in America, and in the next breath said that the military pension looked too much like government charity for the poor. They frequently invoked the British pension and poor law systems in debates over widows' pensions. Representative Eldred Simkins of South Carolina opposed expansion of the pensions afforded traditional war widows, warning that America would go the way of the motherland: "The history of England . . . afforded a commentary on such policy; by the operation of her poor law and her pension system, she had slided into an expense so great that even the air they breathed and the light of heaven, were become subject to taxation."193

190. 31 Annals of Cong. 873 (1818).

191. Ibid., 874.

192. 33 Annals of Cong. 378-79 (1818).

193. Ibid., 396. See also 31 Annals of Cong. 150 (1818) (statement of Senator William Smith) ("All the despotisms of Europe have had their foundations in a claim to military merit. All their pensions and places originated in it."); ibid., 156 (statement of Senator Nathaniel Macon) ("[The opinion that Republics are ungrateful] has been promulgated by the flatterers and sycophants of kings and despots, to become their favorites and pensioners, to live sumptuously on their folly or wickedness, or both, on the profits of the labor of those who were more virtuous and better than themselves. The opinion is founded in idleness 
For Harrison, this critique missed a more striking comparison: to the extent that America's military pension system treated citizens and families differently based on their class-salient status, it already resembled the despotic pension regimes of Europe. There could be no "analogy between [the pension system] of this Government and of the Governments of Europe," Harrison contended, "the one being of moderate extent, and for actual services, the other of enormous extent, and bestowed on the principle of favoritism merely." Here, he said, were individuals "who have contributed their all to the service of the country - the parent who supported and educated the child; the husband on whom the wife depended for protection and subsistence." 194 Echoing the insistence that "equal claims or sacrifices should meet with equal rewards," Representative Henry Southard of New Jersey explained that "in monarchal and despotic Governments, injustice and oppression may answer; but in a Republic, a different line of conduct must be pursued." If the "interest of despots is . . by oppression to extort obedience and command their services . . . . our interest is to be just and liberal to that class of citizens upon whom the liberty and independence of their country so much depend." 195 In the minds of pro-pension legislators, equalization of military widows' pensions followed from elementary republican principles.

These legislators' arguments in favor of expanding widows' pensions to include widows of non-officers were surely tied to a larger set of claims concerning men's status and the rights of the citizen-soldier in the wake of the War of 1812. Most notably, the War of 1812 served as a crucial stimulus for the movement for manhood suffrage among white men who were mustered into the militia, as the very process of being mustered gave them both opportunity and special cause to protest their disenfranchisement. ${ }^{196}$ In addition, in the aftermath of that war, Revolutionary War veterans agitated successfully for the expansion of veterans' service-based

and hatred to free Governments, where every man ought live by the sweat of his own brow . . . ."); Cong. Globe, 27th Cong., 1st Sess. 74 (1841) (statement of Representative Thomas Gilmer) ("It ought to be remembered by every citizen of a free Republic, that, under our forms of Government, while the soldier hazarded his life and spent his time or his fortune for the public good, he could look to none of those rewards which, under European Governments, were so frequently bestowed as marks of public honor."); and source cited in note 222 .

194. 33 Annals of Cong. 394 (1818).

195. 31 Annals of Cong. 875 (1818).

196. J. R. Pole, Political Representation in England and the Origins of the American Republic (London: Macmillan, 1966), 206-9; and Alexander Keyssar, The Right to Vote: The Contested History of Democracy in the United States (New York: Basic Books, 2000), 31 . 
pensions. ${ }^{197}$ In that effort, the image of the citizen-soldier had been successfully harnessed by organized veterans' groups and individuals to secure service-based pensions for Revolutionary War veterans of all ranks, affirming the centrality of military service as a hallmark of full, participatory citizenship. ${ }^{198}$ The growth of widows' pensions similarly helped solidify non-elite men's status as husbands and citizens, as widows' pensions indirectly rewarded all married men who had served the nation. ${ }^{199}$ In this regard, widows' pension statutes were part of a shift, albeit limited, toward democratization of men's citizenship rights during the "era of the common man." 200

It would be wrongheaded, however, to understand widows' pension statutes only in terms of what they signaled concerning men's status. Widows' pension petitions pushed Congress to acknowledge common women's particular contributions and vulnerabilities as wives and widows with financial support from the federal coffers. And, as discussed above, the petitions did so by drawing on contemporary discourses of domesticity. In this regard, it comes as little surprise that the two most significant widows' pension statutes were enacted in the $1830 \mathrm{~s}$, as the concept of domesticity was crystallizing in various cultural forms. Women had long been understood as the keepers of the hearth, but the notion that women possessed special traits and talents that suited them for homemaking and child rearing took on new force and significance as it was refined and reproduced in sermons, magazines, advice books, novels, and poems. ${ }^{201}$ A woman's highest and most appropriate calling was in the home, where she should nurture and instruct her children and exert moral and religious

197. See Jensen, Patriots, 66-79; Resch, Suffering Soldiers, 84-118.

198. See Resch, Suffering Soldiers, 2-3.

199. It is relevant to note that the first service-based pension statute for Revolutionary War widows, enacted in 1836, technically extended the pensions that had been awarded to Revolutionary War veterans to their widows. See discussion in note 24.

200. Characterization of the Jacksonian period as the "era of the common man" was significantly discredited by historians in the 1960s and 1970s. See, for example, Edward Pessen, Jacksonian America: Society, Personality, and Politics (Champaign: University of Illinois Press, 1969). More recent work by Sean Wilentz has revitalized interest in the Jacksonian period, and the conviction that it was marked by distinctive "democratic" changes in national and local politics. See Sean Wilentz, The Rise of American Democracy: Jefferson to Lincoln (New York: Norton, 2005); see also Jeffrey L. Pasley, "Minnows, Spies, and Aristocrats: The Social Crisis of Congress in the Age of Martin Van Buren," Journal of the Early Republic 27 (2007): 599-653. One need not resolve this debate to recognize that claims to egalitarianism - and opposition to values associated with aristocracy — were a salient feature of political discourse during the period. Debates over widows' pension petitions suggest that the creation and expansion of widows' pensions was in part fueled, or at least justified, by "democratic" values of the era.

201. See Cott, The Bonds of Womanhood, 7-9. 
influence on all those residing in the household. ${ }^{202}$ Debates over widows' pensions therefore reveal that, although such beliefs concerning women's inherent capacities were routinely used to justify women's exclusion from direct political participation, they were also used to enhance widows' claims to public material support. In this respect, women's inclusion in, and exclusion from, matters of public concern shared the same ideological foundation.

It is worth underscoring, moreover, that the growth of widows' pensions demonstrates that by the 1830 s, domesticity was being recognized and reified as a concept that was important, not just for women of the upper and middle classes, but for women across the socioeconomic spectrum. ${ }^{203}$ At a time when judges and legislators were beginning to recognize and exploit the social welfare function of marriage for a substantially larger set of women in other areas of law, ${ }^{204}$ widows' pension petitions sounded the horn of common women's domestic contributions, dependency, and need. Through those petitions, women's understanding of their rights as wives were brought to bear on the legislative process, creating a feedback loop between women and national legislators. Whether through firsthand knowledge or newspaper reports, women such as Catharine Barr knew about other widows who had received pensions: both poor widows like herself and wealthy widows like Susan Decatur. ${ }^{205}$ Barr used that knowledge to frame her claim, defending the merits of her view that poverty and dependency, not rank or status, were proper reasons to allocate public monies for military widows' support. Others like her did the same in their petitions to Congress, thus serving as a conduit for a new way of understanding the purpose and function of military widows' pensions, and helping to entrench marriage as a national institution.

\section{Leveling Down: Disestablishing Class-Salient Widows'Pensions}

While actual petitions of widows, along with visions of hordes of impoverished widows arriving in Washington, prompted legislators to reason about the poverty of a substantial class of women as a problem that should be addressed by the national government, reactions against aristocratic privilege also played a central role in shaping and equalizing the widows' pension system. If any widow's petition bore the imprint of the "wild

202. Ibid., 8 .

203. See Carl Degler, At Odds: Women and the Family in America from the Revolution to the Present (New York: Oxford University Press, 1980), 111-43 (observing the salience of the concept of domesticity even among lower-class women).

204. See discussion accompanying notes 165-73.

205. See note 97. 
profusion and extravagance" of Europe, it was Susan Decatur's. ${ }^{206}$ Although she was ultimately successful in obtaining private relief from Congress, many legislators resisted her petitions precisely because her claim was cut from the cloth of Old World privilege and entitlement. Decatur's extraordinary legal saga is, therefore, significant as a legal artifact, not only because her case resulted in a significant Supreme Court opinion concerning mandamus, ${ }^{207}$ but because her petitions to Congress, and the petitions of women like her, prompted reconsideration of whether-and, if so, how - the federal government should use marriage as a basis for public entitlements.

Decatur's petitions to Congress leave little doubt that her claim to an entitlement was founded on a class-salient understanding of widows' legal rights. Although Decatur pled poverty, the papers submitted with her claim spoke of Stephen's heroism in Tripoli- "admirable for the chivalry of its conception, and the brilliant and decisive manner of its execution"- and bore endorsements of Decatur's powerful connections in Washington, D.C. ${ }^{208}$

Such patronage gave Decatur access to legislators that very few other widows enjoyed, and those connections undoubtedly secured the votes of some legislators, but Decatur's bald resort to connections outraged the sensibilities of others. In 1834, Representative Thomas Chilton of Kentucky spoke about Decatur's petition, which by that point had been before Congress in various forms for 9 years. Chilton complained that Congress was being called upon to "appropriate an enormous sum" to benefit "a lady, having, as I understand, a large real estate in this city [and] not a child on earth to provide for," while "countless hosts of widows were left, with crowds of helpless children around them in double orphanage, for whom no provision has ever yet been made." These women, Chilton observed, would have little chance of securing a pension, or even obtaining acknowledgement of their petition, from Congress:

Suppose, sir, that some poor and obscure woman should come here, who has eight or ten children, in the rags of poverty, and, perhaps, without even bread to eat? Suppose she should say to Congress - "Gentlemen, my husband, the father of these suffering children, left his humble fireside and his home- he left me and these. He went forth and fought your battles... Give me and my children thirty thousand dollars." What would be the reply? Ah me! How few the eloquent tongues that would respond, Here take it, it is yours. And should

206. The phrase is Representative Harrison's. See 33 Annals of Cong. 377 (1818).

207. See Decatur v. Paulding, 39 U.S. 497 (1840).

208. Committee on Naval Affairs, On the Claim of Mrs. Susan Decatur, H.R. Rep. No. 19-281 (1826). See sources cited in note 55. 
she even ask, more modestly, for one thousand, or five hundred-the reply would be, in substance, "Depart, for we know you not.". . . An officer, having a great name, has only to demand and receive his thousands, or his tens of thousands; while the poor soldier . . . is forgotten. ${ }^{209}$

Chilton's disillusionment with Decatur's case was of a particular moment: In 1834 Congress was actively considering significant expansion of the demographic reach of widows' pensions. But antipathy to Decatur's quest for a pension was enduring, re-emerging in legislative debates at different junctures. In 1856, for example, Senator Clement Claiborne Clay of Alabama objected to Decatur's claim. "There are petitions without number," he exclaimed, referring to the unsatisfied claims of other widows, and then noted that his "recollection is that [Decatur] has already been the recipient of more bounties from this Government than the widow of any other officer of our Navy." 210

In Decatur's case, the backlash against privilege and private bills appears to have played an unusually direct role in shaping the public law. When Decatur submitted her first petition, in 1825 , private and public acts that provided for officers' widows only were giving way to a new, more egalitarian understanding of military widows' pensions that would help precipitate the enactment of two far-reaching general widows' pension statutes in 1836.211 Seen in light of this leveling trend, it was not simply a coincidence that on the same day that Congress finally enacted a private pension act for Susan Decatur-March 3, 1837-it also enacted the extraordinarily broad general pension statute, appropriately titled "An Act for the More Equitable Administration of the Navy Pension Fund." 212 This general pension statute for navy widows not only reached widows of the rank-and-file, but also awarded lifetime pensions - retroactively and with arrears - to all navy widows whose husbands had "died while in service,"213 rather than "by reason of wounds received in the line of duty," as was the case with most traditional war widows' pension statutes. ${ }^{214}$

209. 10 Reg. Deb. 3820-21 (1834).

210. Cong. Globe, 34th Cong., 1st Sess. 1582 (1856). Impatience with Decatur's claim was palpable even in discussions of parliamentary procedure. Objecting to a motion to take up Decatur's bill out of order under Senate rules, Senator Richard Brodhead of Pennsylvania, former Chairman of the House Committee on Revolutionary Pensions, sniped, "I hope we shall not go beyond one o'clock with this bill for the relief of Mrs. Susan Decatur. I have heard a great deal of Mrs. Susan Decatur since I have been in Congress for the last ten years." Ibid., 1600.

211. See The First System of Public Marriage-Based Entitlements (text section I).

212. Act of March 3, 1837, ch. 38, § 1, 5 Stat. 180, 180.

213. Ibid.

214. Cong. Globe, 26th Cong., 2nd Sess. App. 81 (1840) (statement of Representative Charles Shepard) (explaining that by the 1837 Act "a new doctrine was slipped into the 
The extraordinary generosity of the March 3,1837 act is best understood as part of a direct reaction to Congress's private act for Decatur. Although no record of the legislative debate for the 1837 statute seems to have survived, ${ }^{215}$ debates held just 3 years later, as Congress contemplated its repeal, are telling. The broad scope of the act had nearly bankrupted the navy pension fund. As the House considered the extremely unusual step of repealing a widows' pension statute, ${ }^{216}$ it charged Representative Charles Shepard of North Carolina with determining why Congress had enacted such a generous statute in the first place. His investigation led him to Decatur. Shepard explained that "a portion of the [navy pension] fund had been given to Mrs. Decatur by a special act, and therefore it was thought reasonable to invite other widows and orphans to partake of what had been sacredly devoted to a different purpose." ${ }^{217}$ In other words, in a reaction to the generous relief awarded to Decatur by private act, Congress had attempted to secure a "more equitable administration of the navy pension fund" 218 by passing a general pension law that entitled an enormous class of navy widows to pensions on the same terms as those provided for Decatur. Because Stephen Decatur had not died of battle wounds, but had been in the naval service when he died, the public act also accommodated widows whose husbands had "died while in service." In addition, like Susan Decatur's private act, the general pension statute awarded pensions retroactively to the date of the husband's death. Congress's resistance to special treatment of high-status widows like Decatur led it to significantly expand the general pension laws to reach all navy widows on the same terms.

The March 3, 1837 legislation is only one example of how national lawmakers' suspicion of patrician widows' claims for private relief led to a

statute-book; it gave pensions to the widows, and, if no widows, to the children of officers, seamen, and marines, 'who have died or may hereafter die in the naval service.' However unjust or impolitic previous acts had been, they were not complained of, because the benefit accrued to the relatives of such as 'were killed, or died by reason of wounds received in the line of duty' - but now if a sailor should die from an ordinary disease, or the constitution of an officer be broken down by dissipation, their widows and children are entitled to the same pensions as those of the men who fall in battle.").

215. Ibid., 80 (statement of Representative Charles Shepard) (observing that the 1837 Act was "not discussed, [and] the yeas and nays were not taken on its package").

216. To my knowledge, in the early nineteenth century Congress repealed a widows' pension statute on only one other occasion: in 1824, it repealed an 1817 statute that expanded pension eligibility to widows whose husbands had died of disease while in the line of duty. See Act of January 22, 1824, ch 15, § 2, 4 Stat. 4, 4 (repealing Act of March 3, 1817, ch. 60, 3 Stat. 373).

217. Cong. Globe, 26th Cong., 2d Sess. App. 80 (1840).

218. Act of March 3, 1837, ch. 38, § 1, 5 Stat. 180. 
leveling up of military widows' pensions more generally. ${ }^{219}$ The Congressional Globe provides a full account of the lengthy debates over a petition submitted by the widow of President Harrison, a man who had spent his early days in Congress advocating for the equalization of widows' pensions. Upon her husband's untimely death, Anna Harrison petitioned Congress for a pension of $\$ 25,000 .{ }^{220}$ Harrison's petition, which unfortunately for her was presented at the same time that the legislators were considering the repeal of the overly generous act of March 3, 1837 , became another lightning rod for debate concerning the propriety and scope of pensions for patrician widows. ${ }^{221}$

Some senators used the debate over Harrison's petition as an opportunity to criticize the widows' military pension system more generally, but the great weight of the concern was that pensions awarded to elite widows like Anna Harrison smelled of aristocratic pretension and privilege. During the floor debate, Senator Thomas Benton of Missouri sought to "exemplify the evils of [a] system of civil pensions, by showing what it had produced in England" by reading off a long list of well-known placemen and place-ladies who lived off the public treasury. ${ }^{222}$ Senator Perry Smith of Connecticut conceded that Harrison was a "worthy lady," but argued that were an inquiry made, "it would be found that she had a better property than many that are considered wealthy in the United States." $\mathrm{He}$ summarized what by then appeared to be the prevailing view of Congress: "Was not the sympathy of Congress more appropriately due to the widows

219. As early as 1815 , the Annals of Congress contains a brief summary of a "debate ... of some interest" concerning a pension petition brought by the widow of Vice President Elbridge Gerry. "The general principle asserted by those opposed to the pension was the impropriety of setting a precedent of pensions for civil services, which would entail on the United States the evils so grievously felt in despotic Governments, from the same source." 28 Annals of Cong. 1173 (February 20, 1815). Not all petitions submitted by widows of famous men were denied. For example, although a petition submitted by Alexander Hamilton's widow Elizabeth in 1810 was initially rejected, she was eventually granted 5 years of back pay allegedly owed her husband. See Committee on Pensions and Revolutionary Claims, Claim of the Widow of Colonel Alexander Hamilton for Commutation, H.R. Rep. No. 14-299 (1816). However, Elizabeth did not receive a pension per se until 1838, when she became entitled to a service-based widows' pension under a law of general applicability, the Act of July 4, 1836. See File of Elizabeth Hamilton, NARA, Records of the Department of Veterans Affairs, RG 15, Series M804, W 13402, Pension Office Summary of Record.

220. See Cong. Globe, 27th Cong., 1st Sess. 104 (1841).

221. Debates over Harrison's pension petitions yielded at least 22 pages in the very small font of the Congressional Globe. See Cong. Globe, 27th Cong., 1st Sess. 67-70; 73-77; 104-11; 116-21 (1841); and Cong. Globe, 27th Cong., 1st Sess. App. 64; 169-70 (1841).

222. Cong. Globe, 27th Cong., 1st Sess. 105 (1841). 
and orphans of those who had equal claims, and who were left in poverty and destitution?"223 Anna Harrison's petition was denied.

The individual petitions filed by widows of high-ranking officers and prominent public servants undoubtedly received more attention from legislators than the individual petitions of common women, but in the longer run congressional debates over their merits likely benefited the Catharine Barrs of the world rather than the Decaturs or Harrisons. Petitions submitted by the widows of high-ranking men often drew attention to widows' claims while also highlighting the inequalities of the inherited practice of providing for the widows of officers only, and of the unrepublican dangers of a system of selective, ad hoc entitlements. At a time when egalitarianism was a frequently celebrated, if not necessarily practiced, social and political virtue, ${ }^{224}$ patrician women's pension petitions tended to push Congress to enact more egalitarian, general widows' pension laws, such as the statutes enacted in March and July of 1836 and the raft of subsequent statutes that dramatically expanded the reach of military widows' pensions over the subsequent decades. ${ }^{225}$

\section{Widows' Petitions and the Origins of Marriage-Based Entitlements}

In urging that we must recognize widows' petitions as a crucial factor in the development of early nineteenth-century military widows' pensions, the goal is neither to overstate the significance of women's petitions, nor to underplay the significance of other political and cultural forces that influenced legislators' voting practices. Other aspects of the political process are crucial to understanding why the widows' pension system evolved as it did, when it did. American political development scholars have rightly trained our attention on the importance of institutional and political factors in shaping law and policy. Most notably, of course, Theda Skocpol's pathbreaking analysis of late nineteenth-century military pensions has heightened our attentiveness to how politics shapes policy, particularly with

223. Ibid., 108.

224. Celebration of social and political equality is often associated with the Jacksonian period, although any robust claims to actual socioeconomic and political equality during that period were put to rest by Edward Pessen over four decades ago. See Pessen, Jacksonian America, 39-58. One certainly does not find evidence that pro-pension legislators sought to secure conditions of social or economic equality for struggling widows. Nevertheless, national legislators' resistance to class-salient widows' pensions are marked by a distinctive distrust of aristocratic entitlement that was undoubtedly informed by a commitment, however limited, to a more egalitarian approach to entitlements.

225. See notes $22-36$ and accompanying text. 
respect to social provision. ${ }^{226}$ Surely, the growth of widows' pensions in the early nineteenth century can in part be explained in such terms. Treasury surpluses and the related tariff debates helped fuel the development of military pensions ${ }^{227}$ (although it is notable that many public law widows' pension statutes were enacted during periods of low reserves). And, undoubtedly, the administrative capacity to respond to widows' claims was a necessary condition of making broad-scale pensions anything more than an empty promise. ${ }^{228}$ Nor should we be naïve about the rhetorical nature of congressional debate. Legislators responded to widows' petitions for a host of reasons, some of which were no doubt completely unrelated to their proclaimed sympathy for the financial distress of the women whose petitions they considered.

But in our rush to find a causal explanation in political processes and institutional conditions that, at first blush, appear to be removed from the lives of everyday women of the early nineteenth century, we should not overlook the central role of widows' petitioning efforts in the development of military widows' pensions. Widows' pension petitions were not window dressing for larger political and institutional processes; they were an integral part of the political and institutional processes that brought the first centralized, broad-scale system of public marriage-based entitlements into being. As demonstrated by the string of widows' petitions that prompted the enactment of the watershed statutes of 1836, the petition was the legal and political tool that widows used to put their needs - as individuals, but with shared experiences - on the legislative agenda. National legislators gradually responded to widows' requests for pensions, and they did so not just for widows of the middle and upper classes, but for widows of all classes. In short, the widows' pension petitions helped render Catharine Barr's spirited proclamation concerning widows' pensions- - $[\mathrm{i}] \mathrm{t}$ is no more than right that our Country should allow us that mite for our own Exclusive use"229_intelligible to her and women like her, and intelligible to men in Congress.

Recognition of the salience of women's petitions in the development of broad-scale marriage-based entitlements helps us to situate the legal claims of women like Decatur and Barr and Tenney on the spectrum of early

\section{See Skocpol, Protecting Soldiers and Mothers.}

227. See Jensen, Patriots, 110-22. Notably, in her searching and careful analysis of the emergence of veterans' pensions in the early nineteenth century, Jensen finds that party politics did not play a significant role in their development. Ibid., 110.

228. See Collins, "Administering Marriage."

229. File of Catharine Davidson, NARA, Records of the Department of Veterans' Affairs, RG 15, Old Wars Pension Files, Widow's File 322, Catharine Barr to Commissioner of Pensions, June 20, 1858. 
nineteenth-century women's legal and political activities. Historians have done much over the last three decades to illuminate the many ways in which, cultural and political barriers notwithstanding, women played significant roles in public life in the early nineteenth century. At the local, state, and national levels of government, women engaged in a range of political processes and rituals, and were deeply involved in party politics and, perhaps especially, social activism. ${ }^{230}$ In these capacities, women frequently exploited contemporary gender ideology — and, particularly, the belief in women's special moral status as mothers - in crafting arguments for a particular course of community or government action.

In a similar fashion, widows' pension petitions functioned as an important vehicle for reinforcing and exploiting gender-based sociopolitical roles that by the 1830 s were deeply rooted in political and cultural discourse: women's important, but dependent, function as domestic helpmates, and men's idealized status as wage earners and citizen-soldiers. Accordingly, widows seeking pensions rarely challenged the gendered values of antebellum society. For example, women did not generally petition for pensions based on their direct services as nurses or camp aides. Although at least one woman sought a pension in part based on her service as a nurse in the Revolutionary War, her claim was rejected by legislators and drowned out by the petitions of women seeking support on the basis of their status as widows. ${ }^{231}$ Similarly, although there were a few known instances of women cross-dressing and enlisting in the military, there was no general sense among women, or even among proto-feminists of the period, that women should be able to serve in the military and benefit from the

230. See, for example, Ronald J. Zboray and Mary Saracino Zboray, Voices Without Votes: Women and Politics in Antebellum New England (Lebanon: University of New Hampshire Press, 2010); Zagarri, Revolutionary Backlash; Portnoy, Their Right to Speak; Allgor, Parlor Politics; Kierner, Beyond the Household; Ryan, Women in Public, 19-42, 130-41; Varon, We Mean to Be Counted; John F. Marszalek, The Petticoat Affair: Manners, Mutiny, and Sex in Andrew Jackson's White House (New York: Free Press, 1997); and Ginzberg, "Moral Suasion Is Moral Balderdash"”.

231. See, for example, Committee of Claims, Martha Twist, H.R. Rep. No. 28-29 (January 11, 1845). Martha Twist was the widow of Stephen Twist, who, she observed, "was in the service of the United States for about the period of fifty years." But Martha also based her pension claim on the fact that "she herself was . . attached to the army for about the same length of time in the capacity of a nurse and laundress and therefore asks that she may receive such assistance as will prove adequate to support her during the rest of her life." The Committee recommended against the pension, noting that "[t]he valuable services of the petitioner are not called into question" but that "they cannot consent to establish a precedent that will open a new class of cases to be adjusted and paid at the treasury." Ibid. 
entitlements granted to men on the basis of such service. ${ }^{232}$ Instead, widows seeking pensions reasoned from and within traditional gender norms, and employed the petition in a way that harnessed those norms to secure material security for themselves and their families.

In this regard, widows' claims to pensions based on women's traditional services as wives and mothers resonated with the contemporary claims of women who sought compensation for household labor. As Reva Siegel has chronicled, in the early nineteenth century women's rights activists advocated for joint property rights in marriage - a significant departure from the regime of coverture, in which nearly all that was hers became his upon marriage, including any income generated by her domestic labor. ${ }^{233}$ Albeit unsuccessful, women advocating for joint property rights sought recognition of wives' contributions to the household economy through their substantial efforts: cooking, gardening, cleaning, sewing, keeping boarders, and, especially, child rearing. ${ }^{234}$ Although certainly progressive in their time, as Siegel demonstrates, women urging compensation for wives' domestic services did not challenge the gendered divisions of labor in the family, and they reasoned quite comfortably within a "separate spheres" tradition. ${ }^{235}$ Nevertheless, by claiming a right to wages for household labor, they were undoubtedly seeking rights as women, or, as we would say today, women's rights.

More idiosyncratically, a woman like Catharine Barr might also have found a kindred spirit in Elizabeth Ware Packard, who in the 1860s publicly fought against her husband's despotic and abusive treatment. ${ }^{236}$ As Hendrik Hartog explains in a careful reconstruction of Packard's ordeal, her husband had committed her to an asylum, as he was authorized to do under the law, because Packard insisted on publicly declaring her views on spiritualism, despite the admonitions of her Calvinist minister-

232. The exceptions, although famous, prove the rule. For example, Deborah Sampson (later Gannett) enlisted in the Fourth Massachusetts Regiment in 1781 as "Robert Shurtleff." She fought in several engagements and was honorably discharged after she was discovered to be a woman. She was pensioned by the state of Massachusetts in the 1790 s and by Congress in 1805. For a rich account of Deborah Sampson Gannett's pursuit of a pension, see Alfred F. Young, Masquerade: The Life and Times of Deborah Sampson, Continental Soldier (New York: Alfred A. Knopf, 2004). Her husband was granted a pension by Congress for her service in 1837. See Committee on Revolutionary Pensions, Benjamin Gannett, H.R. Rep. No. 24-172 (1837).

233. See Reva B. Siegel, "Home As Work: The First Woman's Rights Claims Concerning Wives’ Household Labor, 1850-1880," Yale Law Journal 103 (1994): 1073-217.

234. Ibid., 1086-91.

235. Ibid., 1216-17, 1108-12.

236. See Hendrik Hartog, "Mrs. Packard on Dependency," Yale Journal of Law and the Humanities 1 (1988): 79. 
husband. ${ }^{237}$ At first blush, Packard's energetic resistance to her husband's authoritarianism could be read as opposition to a larger sociolegal marital regime that empowered husbands to control and chastise their wives. But Hartog makes clear that, in her efforts to secure release from the asylum and other forms of vindication, Packard did not seek freedom from marriage laws' constraints on wives' agency. Rather, she sought the "right to be a married woman": the right, in other words, to the protection and support that the institution of marriage was supposed to afford women. ${ }^{238}$ In Hartog's words, Packard wanted "legal confirmation of some version of a distinctively female dependent status." 239 By the very act of petitioning for pensions, and through the formulation of their claims, widows seeking pensions sought a similar recognition, and the material support that they urged should come with it.

To observe that proponents of military widows' pensions reasoned within traditional gender norms does not mean that the very public activities of women petitioning for military pensions can be neatly folded into an account of domesticity advocated by women such as Catharine Beecher, who insisted on the private, moral foundation of women's sphere. ${ }^{240}$ Beecher herself criticized women's participation in the abolitionist petition drives at least in part because she feared that petitioning would lead women away from "their appropriate retirement" and into the "arena of political collision." 241 Widows' pension petitions made no claims to an overtly political role for women, but they certainly drew women into a domain of formal legal and political processes that were dominated by, if not often reserved for, men.

In this respect, widows' pension petitions captured and reproduced the seemingly contradictory cultural impulses that Nancy Cott has demonstrated were characteristic of women's position in the early nineteenth century, and which solidified in the 1830 s, a decade of particularly active pension petitioning and legislation. ${ }^{242}$ As discussed previously, widows' pension petitions built on the logic of domesticity, and urged that the

237. Ibid., 79-81.

238. Ibid., 93.

239. Ibid.

240. See Sklar, Catharine Beecher, 151-67.

241. Catharine E. Beecher, An Essay on Slavery and Abolitionism with Reference to the Duty of American Females (Philadelphia: Henry Perkins, 1837), quoted in Zaeske, Signatures of Citizenship, 115. Alisse Portnoy's account of Catharine Beecher's involvement in the anti-removal petition campaign calls into question Beecher's later suggestion that women's involvement in the abolitionist campaign was problematic because it brought women into an "arena of public collision." Instead, Portnoy argues, Catharine Beecher objected to the abolitionist petition campaign because of her support for African colonization as a remedy for slavery, instead of emancipation. Portnoy, Their Right to Speak, 13-14.

242. See Cott, The Bonds of Womanhood, 7-9. 
state consider women's services in the domestic sphere, as well as their vulnerability as dependents, as bases for public support. However, the petitioning process also engaged thousands of women in a public-sphere activity that, in the exact same decade, took on particular significance as women employed the petition for abolitionist and anti-removal causes. ${ }^{243}$ Although very different in their ambitions, the women who participated in these disparate petitioning exercises arguably laid the procedural foundations for women's increased involvement in the public sphere, both to challenge and to harness the concept of domesticity in order to improve women's lot, legally and materially.

Taken as evidence of the law's force in the everyday life of nineteenthcentury women, then, the experiences of the widows who petitioned Congress in order to secure military pensions provide a textured picture of how the law shaped women's lives and how women shaped the law. Like much legal argumentation today, the contemporary rationales offered in support of widows' pensions seem more expedient and improvisational than overtly political with respect to women's place in the polity. Whether operating in a rarefied world like Susan Decatur or navigating the humbling and byzantine bureaucracy of the Pension Office like Catharine Barr, widows did their best to use the law's processes and authority in order to secure financial assistance. The fact that widows' petitions - and the reasoning they employed - were expedient does not render them any less ideological. Ideology is one's commonsense understanding of the way the world works: "the conception of the world which is uncritically absorbed" and reproduced through culture, social convention, political practices, and law. ${ }^{244}$ Expedience led at least some widows and proponents of military widows' pensions to reason about these pensions as a "right" of married women - a right that grew out of widows' former status as wives. Military widows' pensions, therefore, stand as an example of women's everyday, instrumental use of law in a way that materially improved their lives and, simultaneously, strengthened and entrenched marriage as a source of women's legal status and dependency.

Finally, perhaps what is most significant about the widows' pension petitions is that even as they reinforced marriage as a source of legitimacy and structure for women's citizenship, they also helped transform marriage as an institution. Although marriage is often characterized as a private relationship, it has long served a host of public functions as well.

243. See Zaeske, Signatures of Citizenship, 48-104; and Portnoy, Their Right to Speak, $52-86$.

244. Antonio Gramsci, Selections from the Prison Notebooks, trans. and ed. Quintin Hoare and Geoffrey Nowell Smith (New York: International Publishers, 1971), 242-46. 
Historically, however, marriage's public functions generally did not include creation of an entitlement to financial support from the government. In America, that began to change in the early nineteenth century with the development of federal military widows' pensions. Under the pension statutes, military widows could claim support, not just from their husbands' estates or from other private parties, but from the public coffers. The development of this novel form of legal entitlement-the public marriage-based entitlement-signaled important transformations in the legal and social meanings of marriage. During the early nineteenth century, Americans came to understand that, under certain circumstances, marriage gave a substantial class of women "virtually a vested right" to a public pension upon widowhood. ${ }^{245}$ In this respect, early nineteenth-century widows' pension petitions helped bring about durable changes in the institution of marriage-changes that continue to shape Americans' understanding of marriage and the many entitlements it creates to this day. 